\title{
S. Ivo Alla Sapienza: The First Three Minutes
}

\section{Citation}

Connors, Joseph. 1996. "S. Ivo Alla Sapienza: The First Three Minutes." Journal of the Society of Architectural Historians 55 (1) (March): 38-57. doi:10.2307/991054.

\section{Published Version}

$10.2307 / 991054$

\section{Permanent link}

http://nrs.harvard.edu/urn-3:HUL.InstRepos:32955249

\section{Terms of Use}

This article was downloaded from Harvard University's DASH repository, and is made available under the terms and conditions applicable to Other Posted Material, as set forth at http:// nrs.harvard.edu/urn-3:HUL.InstRepos:dash.current.terms-of-use\#LAA

\section{Share Your Story}

The Harvard community has made this article openly available.

Please share how this access benefits you. Submit a story.

Accessibility 


\title{
S. Ivo alla Sapienza
}

\author{
The First Three Minutes
}

\section{JOSEPH CONNORS, Columbia University}

$\mathrm{T}$ he spectator who stands in the courtyard of the old university of Rome and looks at the chapel of S. Ivo [Figure 1] may be forgiven for drawing two seemingly compelling but in fact mistaken conclusions.

The first is that the entire façade elevation, with its powerful alternation of concave exedra, convex drum, concave lantern, and convex spiral, is the product of a single intelligence designing at a single moment. On the contrary, the design was in constant evolution and is full of discontinuities and changes. As has long been known, the two-story exedra was built by Giacomo Della Porta in 1594-1597 as the façade of his own very different church. But in addition, there is evidence that even the parts that Borromini built underwent radical changes during a long construction process that extended over three pontificates. The drum and interior built for Urban VIII in 1642-1644 were heavily reworked under Alexander VII in $1659-1660 .^{1}$ Furthermore, it can also be argued that the lantern and spiral built for Innocent $\mathrm{X}$ in 1652-1653 were a radical innovation over what had been previously planned, designed to tempt a pope to return to a commission that he had spurned for the first two-thirds of his pontificate. ${ }^{2}$

Thus S. Ivo, embraced or rejected according to the roulette of the conclave, constantly recut and reshaped like a large, plastic object, its very name unstable up to the end of the eighteenth century, exhibits a dynamic and evolving unity, not static fidelity to a grand design. ${ }^{3}$

The second difficulty the spectator will experience concerns the plan. It cannot be grasped by anyone standing outside the church. There are surprisingly few centralized buildings that present this problem quite so acutely, since even in the most complex of them, even in Leonardo's drawings or in Sta. Maria della Consolazione at Todi or in St. Peter's, the experienced viewer can get at least some idea of what is going on inside. Here that is impossible. The huge drum with its six bulging apses, which the construction documents liken to the "six petals of a rose," gives the impression that there should be a corresponding interior with six apses. ${ }^{4}$ Indeed, this is just what is shown on the first published plan of the church, issued by Gian
Giacomo de Rossi in 1684 [Figure 2]. ${ }^{5}$ SS. Cosma e Damiano, an eighteenth-century church in Alcamo, Sicily, shows just the hexfoil interior that we might have expected to find at $\mathrm{S}$. Ivo [Figure 3]. ${ }^{6}$

But in fact the real plan is quite different. Although it is not marked in any obvious way on the pavement, its trace can be seen in the main cornice inside the church, especially when it is read on a wide-angle photograph [Figure 4]. The basic configuration is an equilateral triangle with a semicircular apse swung outward from each of the three sides, and with the three corners cut off by arcs swung in from the angles. To say merely a triangle is to say too little, while to say two interlocking triangles in the form of a six-pointed star is to say too much. Triangle-plus-apses-minus-angles is just right. But even to someone standing inside the church the plan is still difficult to read. Wide-angle photographs are misleading, and it is perceptually very difficult for the eye to take in the whole cornice in a single glance. ${ }^{7}$ And relatively little of the generating triangle is left after the semicircles and corner arcs have done their work, in fact less than a third of each side, and so the general impression is one more of curved walls than straight.

If it is difficult simply to describe the plan of the church as it now exists, it is still more difficult to say how Borromini went about designing it. The first instinct of any researcher is, of course, to look for plans from the architect's own hand, and many do exist among the Borromini drawings preserved in the Albertina. But this path leads over slippery ground. Every one of the famous geometrical plans in that collection dates to the end of the building process, around 1660, not to the moment of genesis in 1642. They are fragments of a large unfinished publication project that Borromini envisaged toward the end of his life with the help of the engraver Domenico Barrière. ${ }^{8}$ They show a simplified version of the geometry of the church, and include all the changes initiated by Innocent X and Alexander VII.

These drawings were found in the early eighteenth century and used by the Roman editor Sebastiano Giannini in the first volume of his projected complete works, or Opera, of the architect, published in 1720. But with Giannini the slippery ground turns to quicksand. Giannini heavily edited the material in front of him, reproducing some Barrière plates and forging 


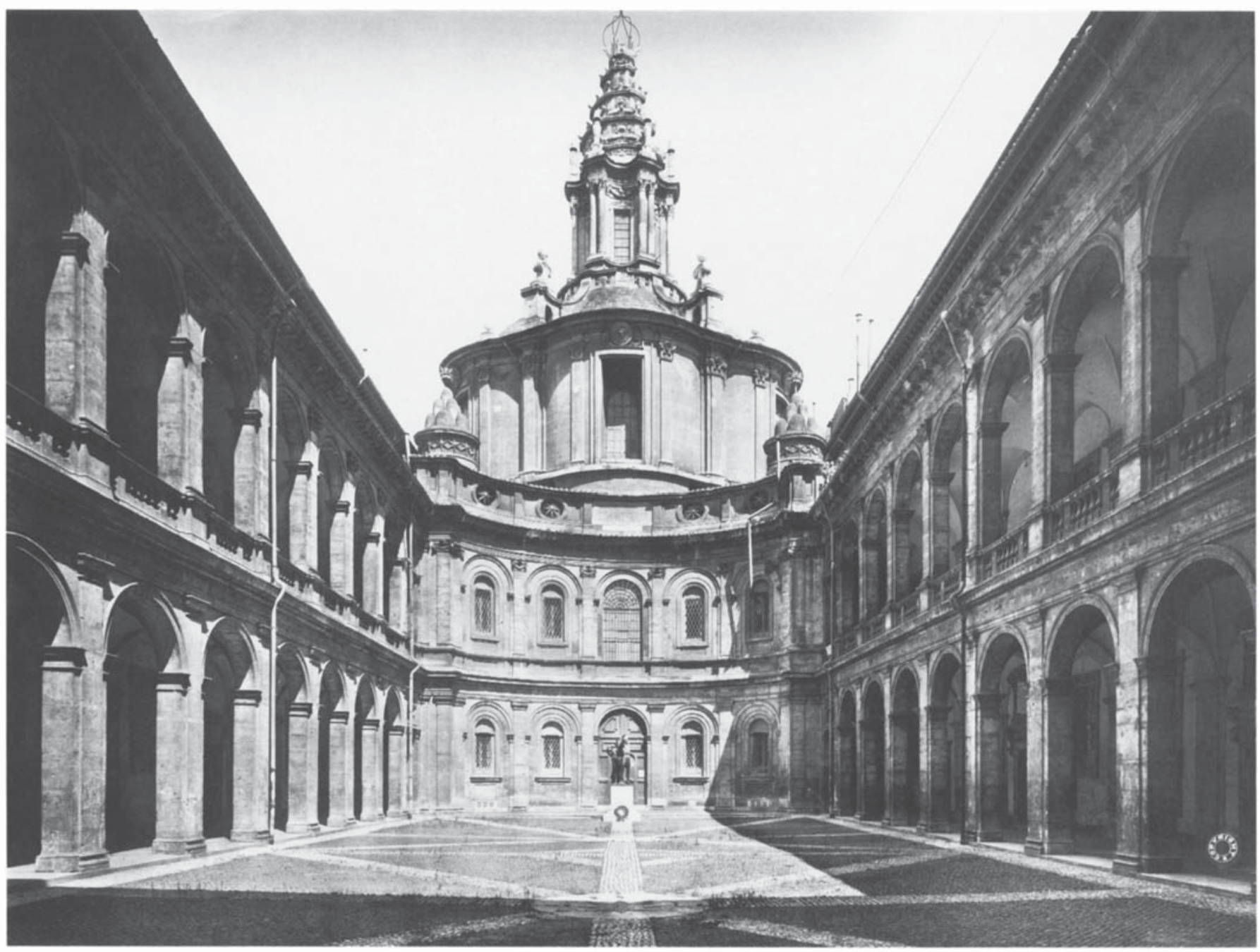

FIGURE I: Francesco Borromini, S. Ivo alla Sapienza, Rome, 1642-1660, with exedra by Giacomo Della Porta, 1594 - I597

others, and redrawing everything in new plates on a vastly enlarged but not necessarily accurate scale. There are indeed some nuggets from the earliest period of the design preserved in Giannini (for example, Figure 19), but often his plates are a pastiche of information taken from many different sources. The pedigree of each print must be established before it can be safely used.

There is only one irreproachable piece of graphic evidence that survives from the earliest period in the design, a presentation drawing in the Archivio di Stato in Rome. ${ }^{9}$ This beautiful, complex plan is the focus of this article [Figures 5 and 6]. It is not the inspired sketch in which Borromini first conceived his brilliant idea and which, if ever found, might allow us to peer over his shoulder in "the first three minutes." It is the next step, the careful drawing done over the course of hours and days of intense concentration. The plan was laid out in precise geometrical steps, then moved and enlarged, revised and rethought, each pencil layer vanishing like a ghost under fresh reworking. Finally the plan was fixed in red chalk and submitted as a presentation drawing, though the process of revision and change seems to have continued even after that point.

Unlike most studies of S. Ivo, this article is not an iconographic study. It is concerned mostly with the plan and mostly with the early phase of the design under the Barberini. It attempts to record as faithfully as possible what the ASR drawing actually shows, reconstructing its geometry and giving its measurements. Dry autopsy is to be preferred to exciting iconography, at least for the moment, if the aim is to lay a solid foundation for future research.

Naturally, the plan cannot be discussed without reference to its sources. But I have tried to focus primarily on what might have been available to Borromini in earlier architecture, the world closest to his professional formation. I have assumed that sources from the work of Baldassarre Peruzzi or Giuliano da Sangallo, if indeed they fit closely, and if they reflect a common passion for the antique, will be more relevant than loose-fitting emblems and cosmic diagrams, however avidly they may have been cultivated in some pockets of the Barberini court. Indeed, it will not hurt S. Ivo studies to try to clear the ground of 


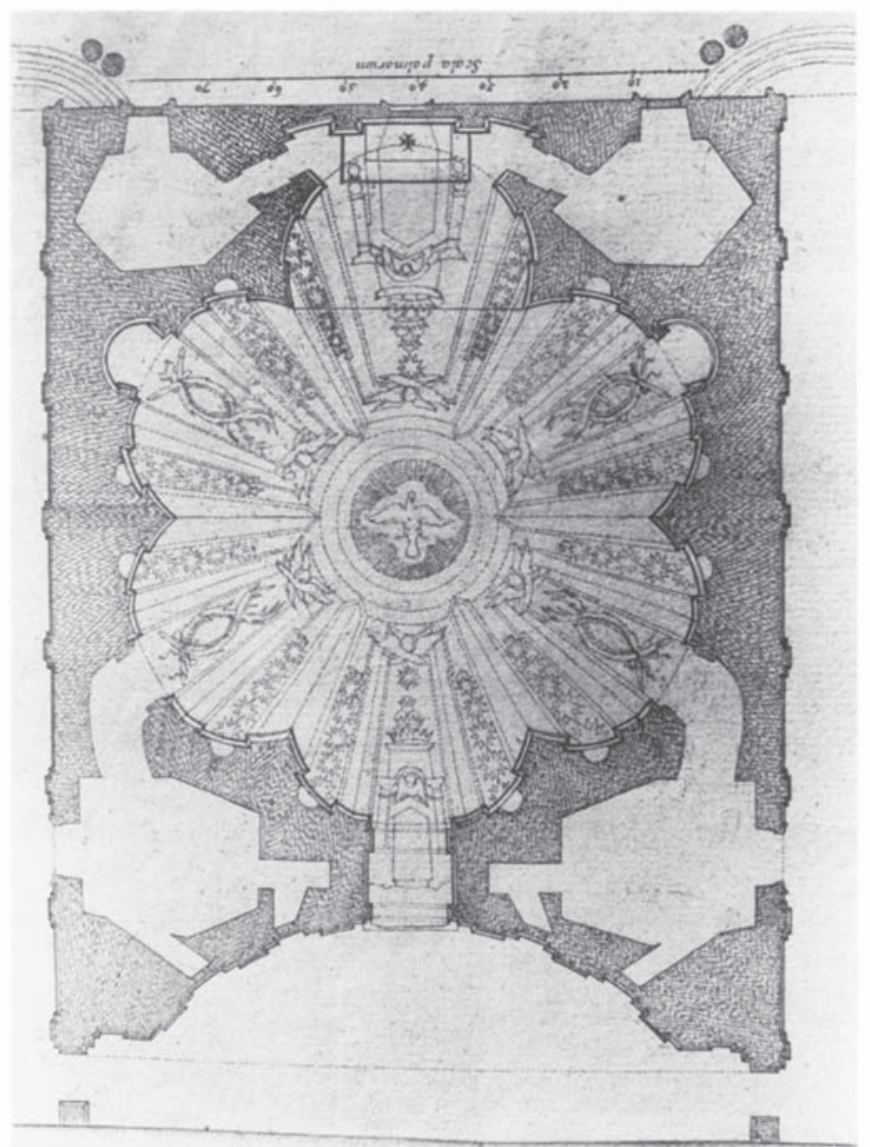

FIGURE 2: G. G. de Rossi, plan of S. Ivo, 1684, etching

improbable sources, or to inject a note of Cartesian skepticism into the discourse, posing the question "Que sais-je?" about the drawings before proceeding to the question of meaning.

\section{The Della Porta Plan}

Borromini inherited a fully developed plan from Giacomo Della Porta, who had worked on the Sapienza for twenty-five years up to his death in 1602. Della Porta's plan was discovered in a miscellaneous volume of architectural drawings in Modena, with the plan on the recto and details of the church and the other wings of the Sapienza on the verso [Figures 7 and 8$] \cdot{ }^{10}$ The plan bears the date 1597, the year when the exedra was finished, but it seems to record a phase just before the definitive wooden model of $1581 .^{11}$ Della Porta envisaged a church with four small chapels on the cross axis, a large altar chapel on the east, and entrances from the side corridors as well as from the exedra. Since the church was not freestanding he realized that it would have to be very tall to reach up to the light. $\mathrm{He}$ designed a two-story interior with arches of differing sizes in the lower zone, some opening onto chapels and some blind. The cupola is shown in section on the verso of the drawing (Figure 8 ). It is a thin shell with a steep curvature leading up to an oculus, the unique source of light, located about 170 palmi off the ground. This is approximately eight and one-half meters

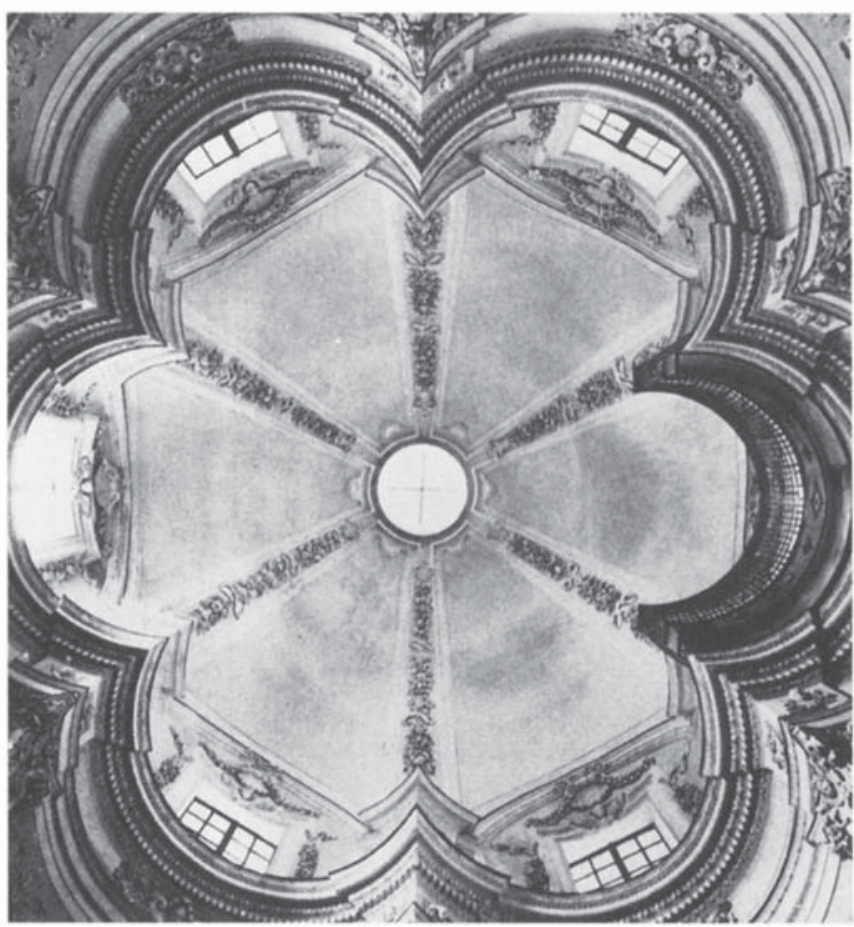

FIGURE 3: Giuseppe Mariani, SS. Cosma e Damiano in the monastery of S. Chiara, Alcamo, Sicily, 1721, view of cupola

higher than the oculus would later be in Borromini's cupola. Indeed, Borromini's towering masonry superstructure- lantern, spiral, and flaming laurel crown (but not the ironwork)-is only only a little more than five meters higher than the opening of Della Porta's oculus. ${ }^{12}$

The question of who really designed the curving exedra is currently the subject of lively debate. Heinrich Thelen, in the first serious study of the building history of the Sapienza before Borromini, argued that the general conception goes back to a grand design of 1565 by Pirro Ligorio, which envisaged not one but two curving exedras at the ends of a long circus-like courtyard. In an innovative recent study of the Sapienza, Michael Kiene accepts Thelen's reconstruction but puts the building into the larger context of Italian university architecture. Robert Stalla accepts Thelen's reconstruction as well, insisting on an Antikenrezeption which can, he thinks, only point to Ligorio; he would have us see the Ligorio project as an atrio del piacere complete with statue program. Manfredo Tafuri reminds us that Borromini's friend Martinelli, in his monograph on the Sapienza written in about 1660, thought that the idea of the exedra went back to a project by Bramante for Leo $\mathrm{X}$, and presumably this was Borromini's opinion as well. Anna Bedon, in a new reconstruction that radically revises the building history, gives much more credit to Della Porta as both ideator and executor; for her, Ligorio plays only a trivial role. All these authors stress the revival, however indirect and confused, of the ancient gymnasion as a prototype for the courtyard with exedra. ${ }^{13}$ 
Whoever thought it up, Della Porta built the exedra in 1594-1597, thus setting the stage for his successor. For many years it stood as a thin screen with blind niches and a bricked-up door between the university courtyard and the private houses that still stood on the eastern end of the block.

\section{The ASR Drawing}

The sheet measures 69.8 by $47.6 \mathrm{~cm}$, while the building itself (including the expansions behind the high altar) measures 66.8 by $45.6 \mathrm{~cm}$. The clear width of the courtyard is $18.5 \mathrm{~cm}$. There are three scales: one in Roman numerals at the bottom of the sheet, along the west façade of the Sapienza; one in Roman numerals at the top of the sheet, coinciding with the original east façade, now heavily overdrawn; and a third scale in Arabic numerals drawn after the final expansion of the building to the top or east. On all three scales 100 palmi $=18.3 \mathrm{~cm}(1: 122)$.

The graphic conventions accord well with a date of 1642 . First, the drawing makes liberal use of red chalk, which, though relatively rare in Borromini's work, finds a close parallel in the plans for Palazzo Carpegna, done in $1638-1640 .{ }^{14}$ Second, the convention of scales in Roman numerals, though common in Borromini's early drawings, goes out of use shortly after 1640 ; the ASR plan would be the last such drawing. ${ }^{15}$ Indeed, when Borromini began to rework the drawing and had to redraw the top scale, he used Arabic numerals. None of these considerations positively excludes a date earlier than 1642, and Borromini was nominated as architect of the Sapienza as early as 1632 , but it seems likely that the drawing was done in the year that witnessed the first preparations for construction. ${ }^{16}$

There are several cautions to be observed when taking measurements on the ASR drawing, above and beyond Rudolf Wittkower's sage warning that the compass in the scholar's hand seldom rebels. First, the sheet has been damaged by the constant folding and unfolding to which it was subjected up to 1989, and it suffered further in the restoration of that year. Photographs taken before 1989 show a crease with some paper loss running down the left side of the church, while photographs taken after 1989 show a gaping hole. This has been repaired in such a way that the sheet is now slightly more contracted on the left than it once was. The two scales at the top (Roman and Arabic) have lost about one palmo on the left side of the drawing; thus it is more accurate to use the scale at the bottom of the sheet, which is undamaged. Second, even using the bottom scale, any measurement that crosses the crease will

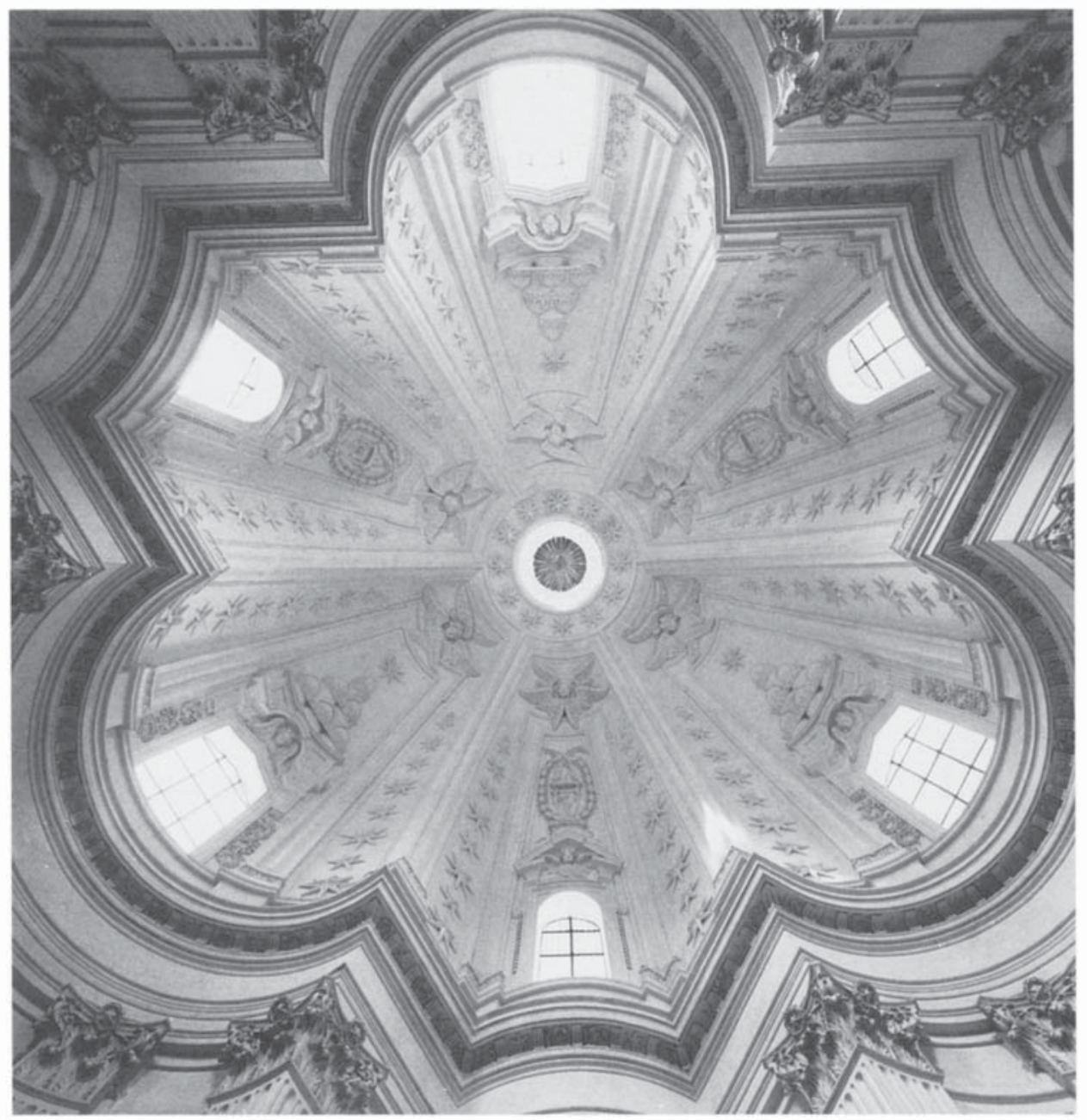

FIGURE 4: S. Ivo, view of cupola 
FIGURE 5: Francesco Borromini, S. Ivo alla Sapienza, presentation project, 1642, pencil and red chalk $(69.8 \times 47.6 \mathrm{~cm})$. North to left

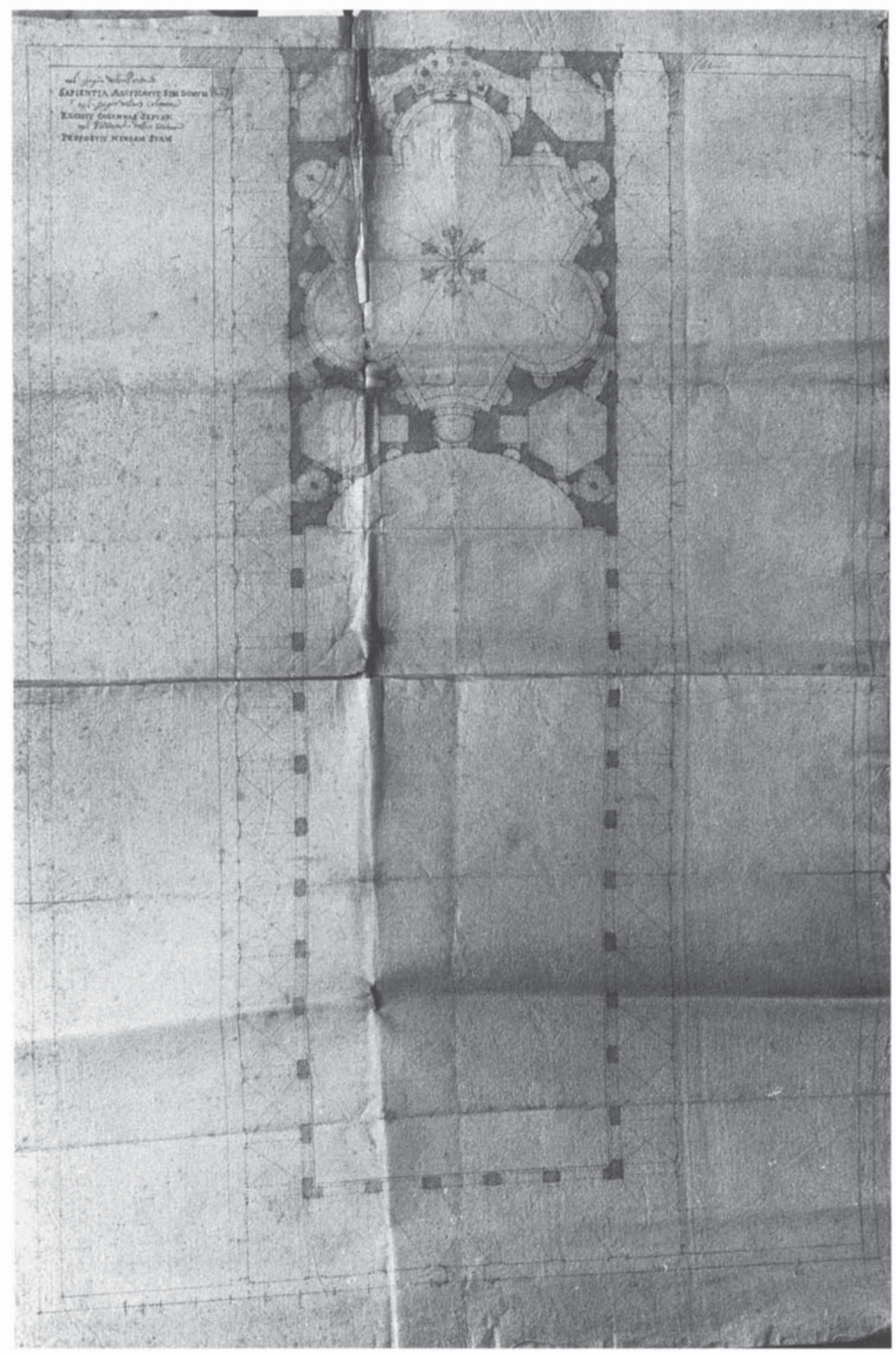

be about one palmo too short. Third, the drawing is in general too small for accurate readings under a half-palmo. ${ }^{17}$

Borromini began by copying the general outline of the building from an earlier sheet like the Della Porta plan in Modena, but larger, and now lost. Della Porta's known plan is on a scale of 1:153, while Borromini's is on a scale of $1: 122$. A glance at the verso of the ASR drawing shows the telltale pinpricks used for transfer from the lost drawing, especially for the piers of the courtyard. But in the area of the church these disappear, and one finds only the seemingly random holes made by the designing architect's compass.

Beneath the final plan of the church is a barely visible underimage. On some Borromini drawings, notably an early plan of S. Carlino, these ghost images can reveal designs that are completely different from those on the uppermost strata. ${ }^{18}$ Here the case is less drastic, though still worthy of note. The ASR drawing simply shows an earlier version of the equilateral triangle, different not in form but in size and position from the 


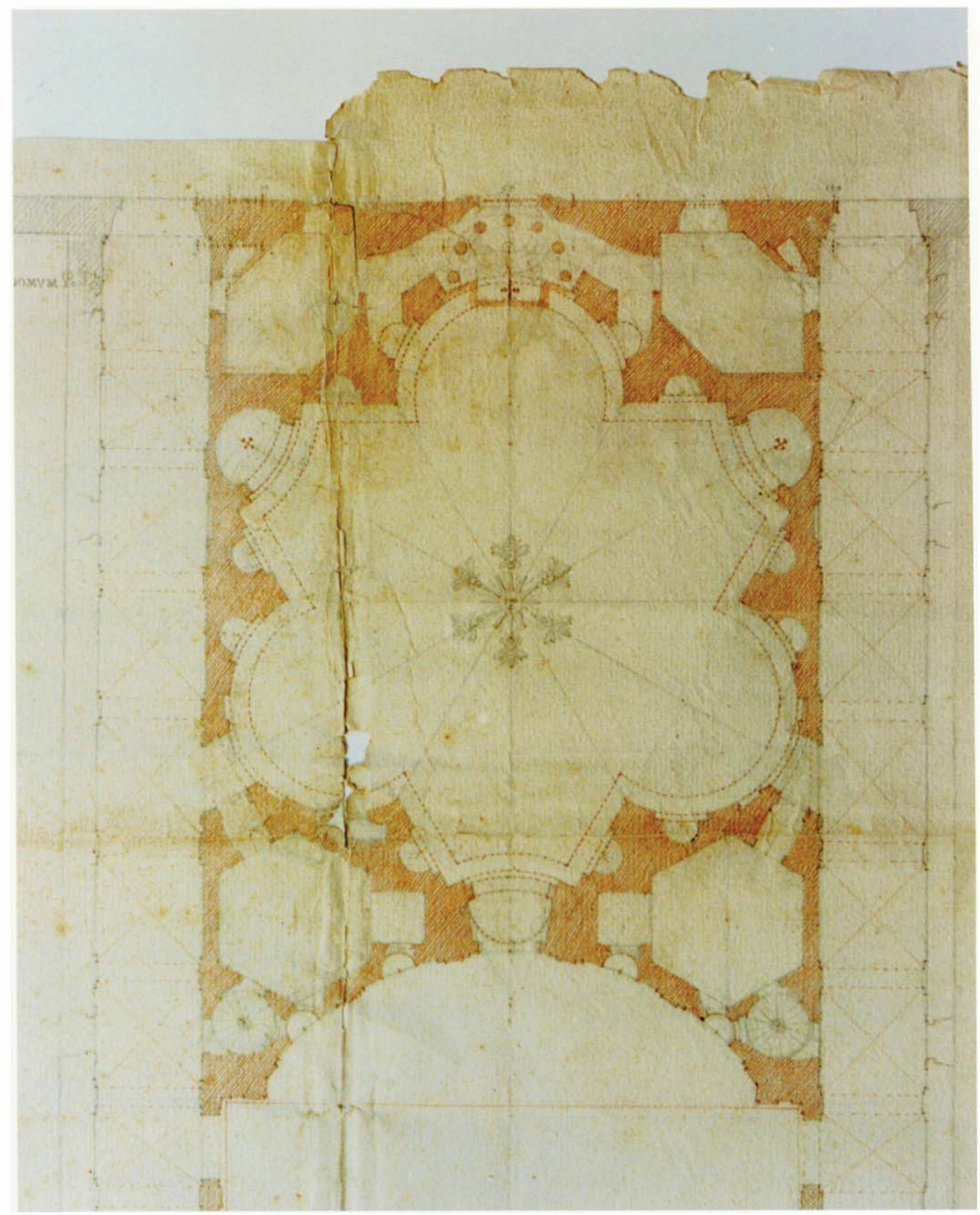

FIGURE 6: Francesco Borromini, plan of S. Ivo in Figure 5, detail 


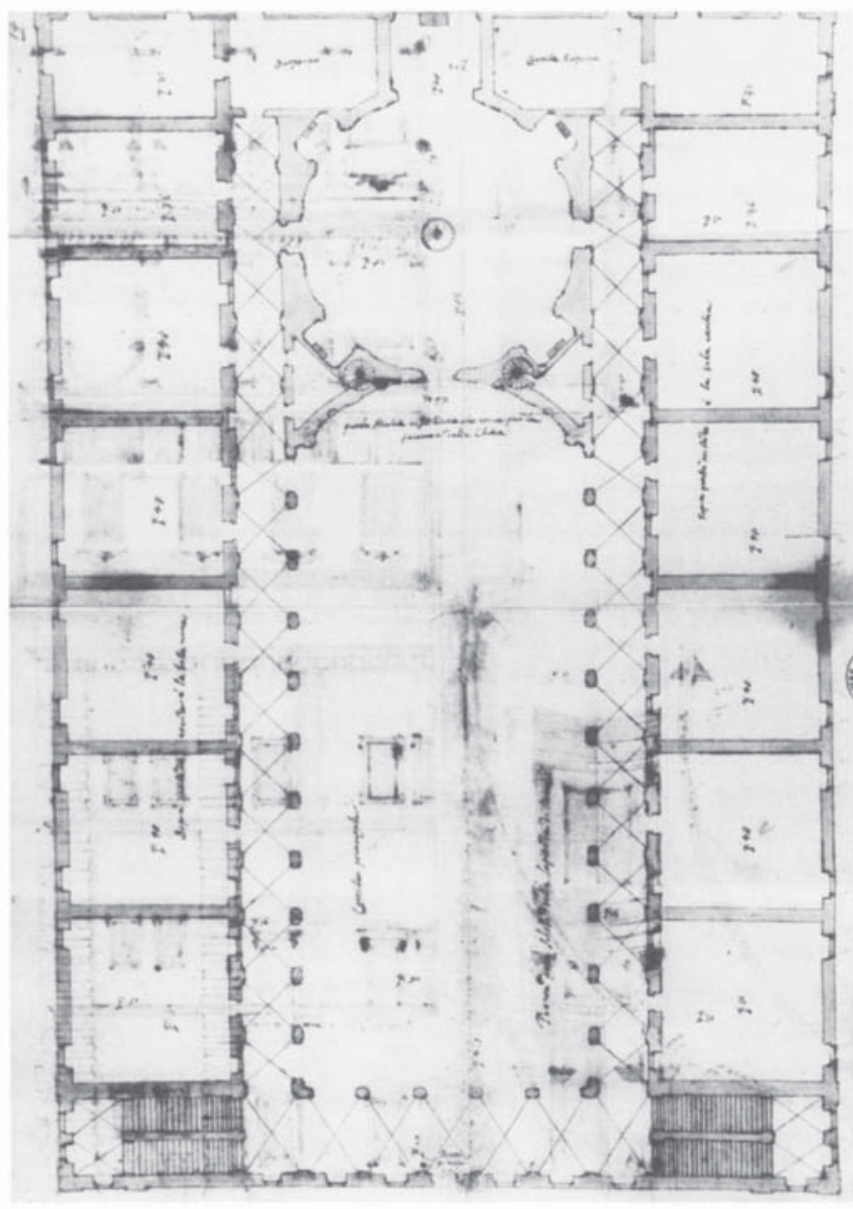

FIGURE 7: After Giacomo Della Porta, Sapienza, Rome, plan of I 597 after a project of c. 1581 , ink on paper $(56.9 \times 43.7 \mathrm{~cm})$

final triangle. It is best rendered in a diagram [Figure 9]. Each side of the triangle measures 102 palmi. Since the space available for the church was only 96 palmi wide, two points of the triangle fall in the corridors, though only slightly. The apses take up one-third of each side, and are drawn with radii of 17 palmi. In the top corners of the triangle Borromini carved out two nicchioni, and in addition there was enough wall mass left to give each of these a small recess for an altar.

The generating triangle was not governed by immutable proportions. It was a template that Borromini could stretch and move until every member of the church was in the position he wanted. In its second and final version the triangle was expanded to measure 106 palmi to a side, and was moved 7 palmi toward the east or top of the ASR drawing. These changes tend to reduce the wall mass to the absolute theoretical minimum. (One feels that the triangle used for the actual construction must have been contracted, since the bearing walls could not possibly be this thin.) On the ASR drawing two points of the triangle now fall far out in the corridors. The two nicchioni eat so deeply into the wall that they lose their altar recesses. By the time the church was built the nicchioni had no clearly defined function, and although they might have served as chapels or

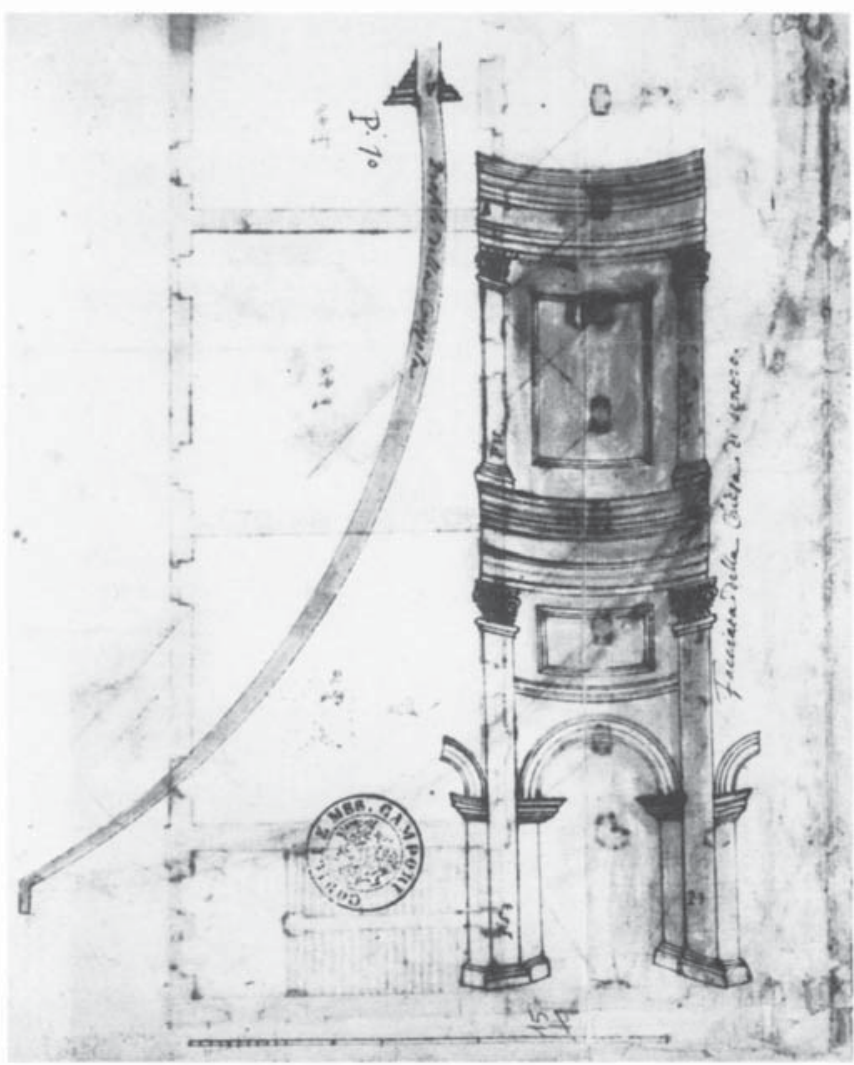

FIGURE 8: After Giacomo Della Porta, Sapienza, Rome, section of chapel and cupola (detail of the verso of Figure 7), ink on paper

statue niches, in the end they became simply targets for lines of sight coming from the side doors. ${ }^{19}$ The side doors were originally built just as they are shown on the ASR drawing, with direct entrance from the flanking corridors and huge arched portals, 191/2 palmi high, through which the visitor would have beheld the magnificent cupola in a single glance. ${ }^{20}$

The three apses are formed by semicircles with diameters equal to one-third the sides of the triangle, $35+$ palmi. Inside the triangle, faint but visible, is an inscribed hexagon with sides of $35+$ palmi, and circumscribed around this is a circle with a radius of the same length. Compared to some plans in Serlio and Montano, S. Ivo could not be described as a hexagonal church, but it would later become very important to Borromini to assert that the hexagon lay at the core of the plan. ${ }^{21}$

In all versions of the plan the corners of the triangle are cut off by arcs swung inward from the angles. The question is how to determine the length of these arcs. It is common to construct them using a radius equal to the radius of the semicircular apses, that is, one-sixth the side of the triangle. ${ }^{22}$ Thus the whole diagram seems to have the neatness of a theorem. However, Paolo Portoghesi long ago saw that the angle radii are clearly longer than the radii of the semicircles. ${ }^{23}$ On the ASR drawing they measure 20-palmi, leaving only $16-p a l m i$ for the straight segments of the inside wall. The sides of the triangle are clearly not divided into equal sixths [Figure 10]. 

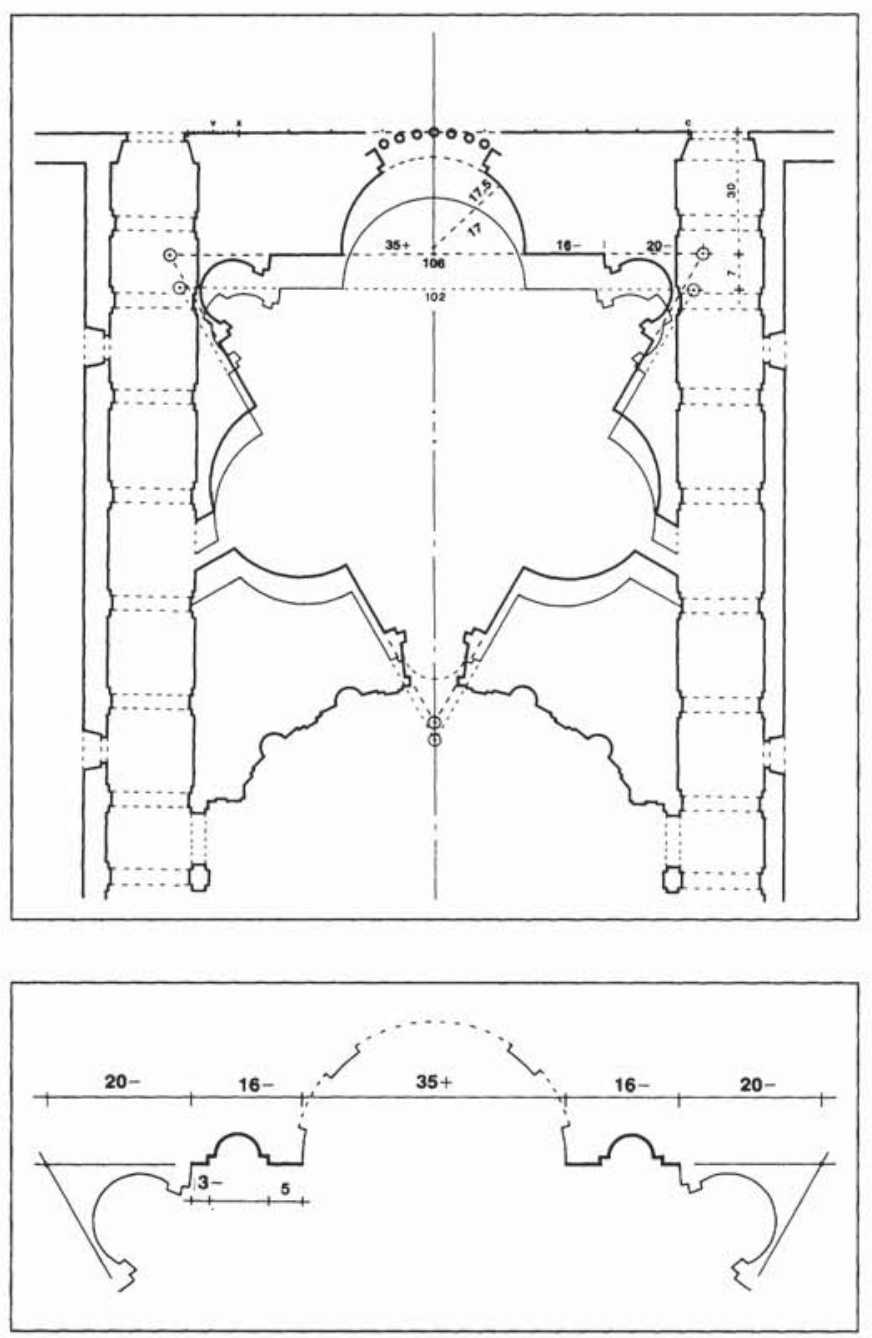

FIGURE 9: S. Ivo, diagram of the two phases of the triangle in Figure 6

FIGURE IO: S. Ivo, measurements of pilasters and niches in Figure 6

Up to a point Borromini arrived at his key points by subdividing a geometrical figure. But at the level of the most minute measurements, the widths of the pilaster faces and the niches, he changed his way of proceeding and used simple whole numbers. The pilasters were made 5 palmi wide, and the niche zone 8 palmi [Figure 11]. Some optical adjustments were made as well. The bent half-pilasters in the angles should logically have been 2.5 palmi but Borromini found it optically more satisfying to stretch them slightly to $3-$ palmi. Once his wall articulation was taken care of (the total comes to $16-$ palmi for each straight segment of wall), he cut off whatever happened to be left over at the angles. This happened to be 20palmi, but it would have been different if the triangle had been expanded or contracted one more time.

Borromini was not looking for proportional solutions, and this is not simply a geometrical construction. The triangle had no sacred status but was just a moving template that could be expanded and shifted at will, its dimensions changing as the plan of the church was fine-tuned to the limit. For Borromini

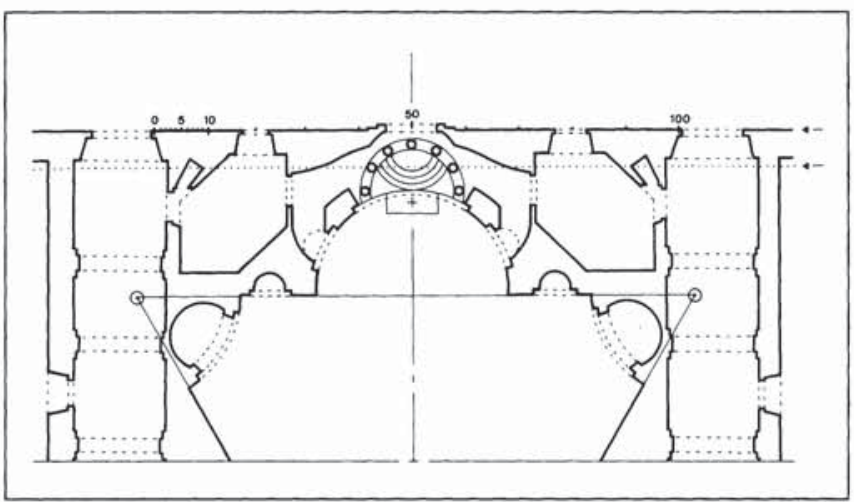

FIGURE I I: S. Ivo, diagram of high altar area in Figure 6

was designing a church, not a theorem, and to do it well he had to have "compasses in his eyes," like Michelangelo. ${ }^{24}$

Every decision on the plan had repercussions in the elevation. For example, the pilaster width of 5 palmi was about as large as the scheme allowed. Yet given the need for the walls to reach up to the light, pilasters only five palmi wide would end up being about 55 palmi high (counting bases and capitals). This makes a proportion of $1: 11$, which is extraordinarily slender. Della Porta had avoided the problem by using two orders, one above the other, but this was not Borromini's way. Although he was in fact building a lower cupola than Della Porta's, he knew the rules of optical illusion, linganno dell'occhio. The base of the drum is stilted to an amazing degree. The great cornice, although it appears to be at about two-thirds the height of the interior to anyone standing in the church, is in fact only at the halfway mark. The upper zones are steeper and taller than the earthbound spectator could ever imagine. To open the door of one of the hatches that give out onto the cornice is a vertiginous experience, but also a revelation of the sensitivity to height that the architect exercised while working on the plan. ${ }^{25}$

To return to the ASR plan: the triangle-plus-apses-minusangles is used to delineate the pilaster faces. But the wall face was set farther out and a cornice drawn farther in. The altar niche was given greater depth than the others by being generated from a point set slightly back from the triangle, making this semicircle greater than 180 degrees. The twelve small niches also have a slight horseshoe shape. Apparently Borromini was influenced here by his own observation that the ancient Romans made their niches deeper than semicircles. ${ }^{26}$

The altar area is the messiest and most heavily reworked part of the ASR drawing. Its metamorphoses can be charted (Figures 9 and 11). The primary idea was to give concrete architectural expression to the verse inscribed on the upper left corner of the drawing, "Wisdom has built herself a house, she has erected her seven pillars, [she has slaughtered her beasts, prepared her wine], she has laid her table." ${ }^{27}$ This passage from the sapiential literature of the Old Testament had been given Christian meaning and related to the study of the seven liberal 
arts by Alcuin, and the seven columns had been visualized as an exedra in Byzantine art. ${ }^{28}$ Borromini's task was to design such an exedra in the context of a complex geometrical plan.

Two stages are visible on the drawing. First, Borromini opened up the rear wall of the altar apse in a wide arc, concentric with the apse itself, and along the back of this arc he placed seven small columns, with the center column exactly on the center point of the original Roman numeral scale (Figure 10). Then, caught up in the excitement of the iconographic idea, and maybe even under the influence of more Renaissance drawings, he regrouped the seven columns into a much tighter horseshoe (Figures 6 and 11). ${ }^{29}$ The center of the horseshoe was placed not on the main semicircle, the one that delimits the pilaster faces of the apse, but on a slightly larger semicircle delimiting the wall face. By pushing the altar ever farther back Borromini soon ran out of space and overreached the eastern limit of the building. Undeterred, he moved the rear wall of the building 7 palmi farther out, as though that much land could be taken from the piazza. ${ }^{30} \mathrm{He}$ drew a new scale in Arabic numerals along the new boundary. A very large window, 9 palmi wide in contrast with the $51 / 2$-palmi width of the other windows, was opened in the eastern wall to flood the exedra with morning light.

Borromini may have been thinking of the high altar that Pietro da Cortona built in temporary materials in 1634 in the apse of S. Giovanni dei Fiorentini, where light also flowed around columns onto a sculpture group. ${ }^{31}$ But there is no clear indication of what the statue presiding over the altar of S. Ivo would have been. The inscription on its pedestal, "PROPOSUIT MENSAM SUAM," has a eucharistic connotation. John Scott has suggested that a crucifix would be appropriate, since Saint Paul equates wisdom with Christ crucified. He mentions the formal similarity with the apse of Palladio's Redentore, where the crucifix over the altar has a columnar exedra as a distant backdrop. ${ }^{32}$ But the base shown on the ASR drawing is very large, about 4 by 7 palmi, and the inscription reads "on the pedestal of the statue," not on the base of the crucifix. Possibly the Barberini saw the opportunity to acquire a famous statue. Two of Michelangelo's late Pietàs were available, and both the Passion iconography and the presence of the Virgin would have made them entirely appropriate to the dedication and the inscription. ${ }^{33}$ Or, if they wanted to be more original, Sapientia did have its own iconography. ${ }^{34}$ The question of the statue must, for the moment, be left open.

\section{Sources}

The basic plan has been established as a triangle-plus-apsesminus-angles. The repertoire of Gothic ornament has produced many triangles-with-apses, but so far none with truncated corners. ${ }^{35}$ These we do find, however, on a sketch which was made by Carlo Maderno or Giovanni Van Zanten in 1612-1613,
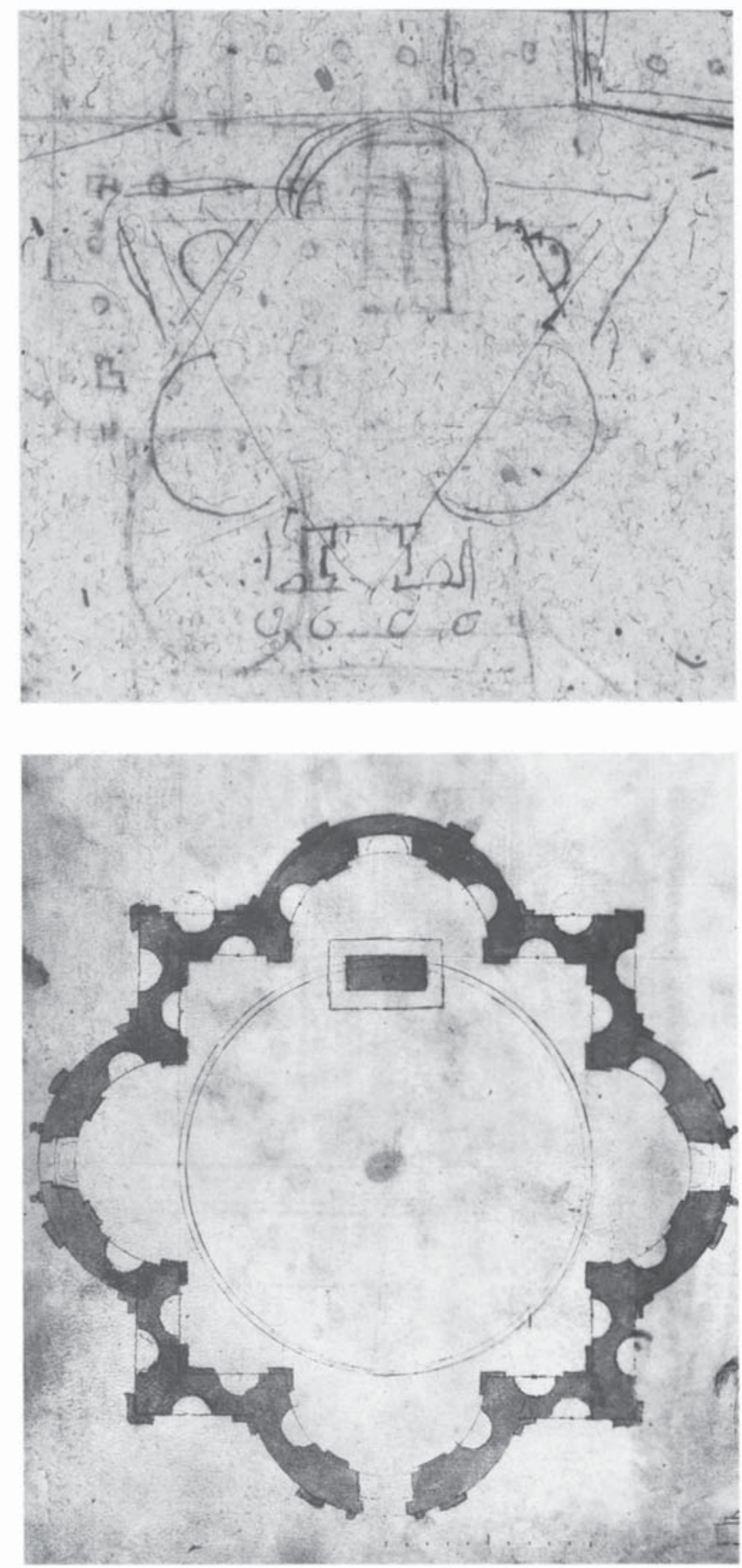

FIGURE 12: Baldassarre Peruzzi, project for a triangular church, pen on paper. Uffizi $U$ $553 \mathrm{~A}$ v, detail

FIGURE 13: Giuliano da Sangallo, plan of an ideal church, pen on parchment, Barb.Lat. 4424, fol. $32 v$

possibly following the design of an ancient fountain. With a few quick flicks of the pen the architect came remarkably close to the plan of S. Ivo. ${ }^{36}$ But the closest precedent for S. Ivo is to be found in a sketch for a triangular church by Baldassarre Peruzzi [Figure 12] ${ }^{37}$ The triangle in Peruzzi's drawing provided the basic armature; wall thicknesses were added almost as an 
afterthought. Two of the angles are cut off by niches with flat faces, while the third angle becomes an entrance with a columnar porch and vestibule like a mini-Pantheon.

Borromini's plan, with small niches cutting into the wall mass behind the great pilasters, has a strangely Bramantesque feeling, reminding one of the parchment plan for St. Peter's and other High Renaissance designs in which walls are eaten away by niches and reduced to filigrane thinness. Space takes its bites, and what is left is an odd "claw pier." 38 Although Borromini may have learned this lesson from many sources, one plan in particular repays close study in the context of S. Ivo. It is a design for a small church by Giuliano da Sangallo in the Barberini Codex [Figure 13]. ${ }^{39}$ The plan is a square with four apses, each half of one of the sides. A circle with a diameter equal to the square delineates the cupola. The altar is placed in one apse while entrances are opened in the other three. The walls are hollowed out by niches eating into them from inside and out, and pilasters bend in or out around the points where the walls and apses meet.

One can imagine Borromini arriving at the plan of S. Ivo by taking Giuliano's plan and reducing it from four sides to three. The result of such a manipulation would be something very much like the ASR plan, with slight changes in proportion (the apses are one-half the sides in Giuliano's plan and one-third in Borromini's). The wall articulation would be almost identical. Even a puzzling feature of the ASR plan, the doors that open in the middle of the two side apses, can be explained as a vestige of Giuliano's plan. It is this kind of playful, transformative thinking that may best elucidate Borromini's attitude to models which he treasured but refused to copy.

It is time to return to the paradox of the cupola, namely, the hexfoil drum that reveals nothing of the triangular plan within. To envisage the exact relationship between the two, it is helpful to turn to a drawing produced by Borromini for the publication project mentioned above. Smaller than the ASR drawing and greatly simplified, the plan at cupola level shows quite clearly the unusual relationship between the exterior and the interior [Figure 14] ${ }^{40}$ For in this matter $\mathrm{S}$. Ivo is a complete exception to the rules that normally governed the cupolas of centralized churches.

In the case of simple rotundas, like the Pantheon or like Della Porta's project for the Sapienza, the cupola is continuous with the cylinder of the walls. When the ground plan becomes complex, like a Greek cross or like Giuliano da Sangallo's church in Figure 13, then the cupola retreats from the perimeter and becomes a smaller circle drawn inside the main figure. Squinches or pendentives are used to bridge the gap between it and the supporting piers or walls. If we were to imagine a cupola on Peruzzi's triangular plan in Figure 12, it would doubtless be equivalent to the hexagon that can be inscribed inside it. ${ }^{41}$ In all these cases, and in many more in ancient and

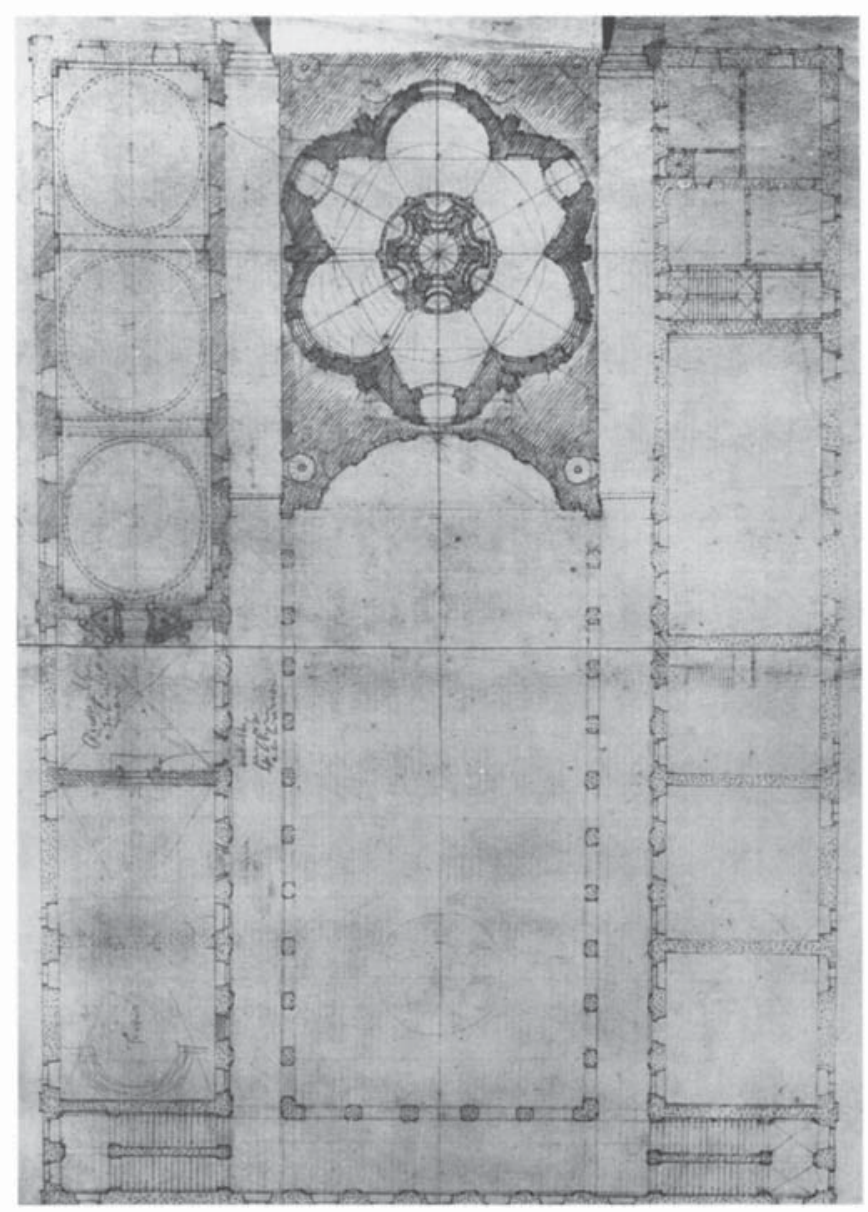

FIGURE 14: Francesco Borromini, idealized plan of S. Ivo at drum level, c. 1660, pencil $(37.6 \times 26.9 \mathrm{~cm}), \mathrm{Alb} .500$ with top flap raised

Renaissance architecture, the cupola is as a rule smaller than the generating figure and inscribable within it. ${ }^{42}$

S. Ivo is unique in that the cupola is larger than the generating triangle and is circumscribed around it. The "six petals of the rose" are drawn as lobes with their centers set on the sides of the central hexagon. Three of these lobes are concentric with the three apses of the interior and easily fit around them. In these cases the windows have perfectly normal jambs. But the other three lobes mesh most awkwardly with the points of the triangle and with their corner-cutting arcs. At these junctures the window jambs are abnormally thick. This is the case, for instance, with the window jamb immediately over the exedra facing the courtyard, which proved so ungainly that Borromini finally filled it with stucco ornament- the lamb, the book with seven seals, and the disk with the Holy Spirit—all drawn from the emblem of Divine Wisdom in Ripa. ${ }^{43}$

Thus in one sense the interior of the vault of S. Ivo follows the "pumpkin-dome" tradition seen in several ancient structures in Rome and in Hadrian's Villa at Tivoli. ${ }^{44}$ But in contrast to Roman domes the complexity of the floor plan is directly communicated to the vault, which is forced into strange contortions by the angular movement of the walls beneath it. ${ }^{45}$ The 


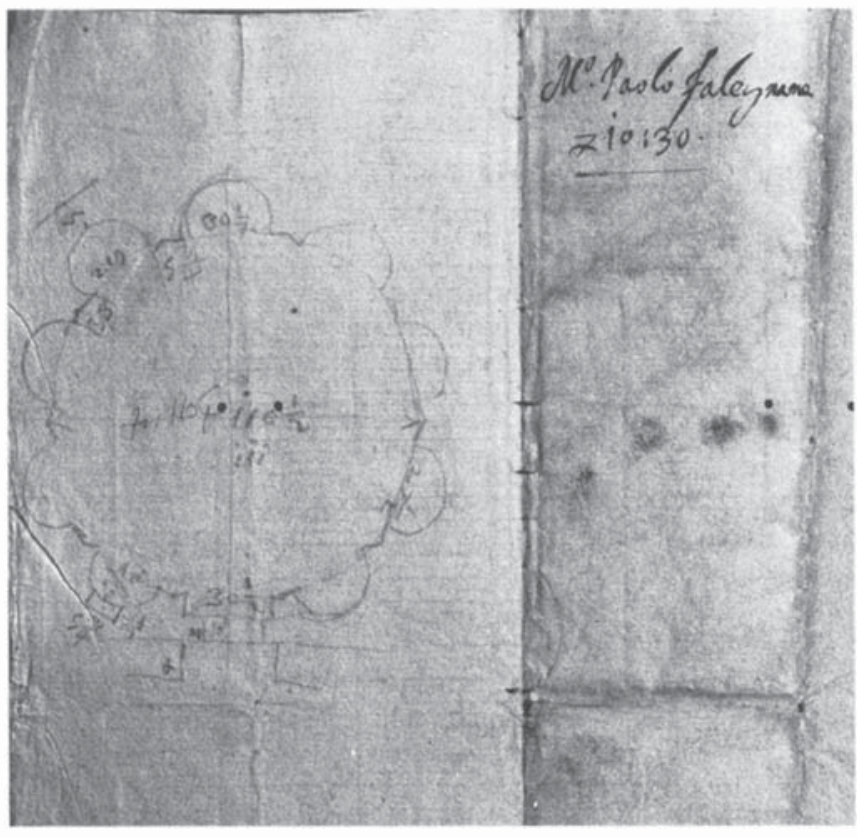

FIGURE 15: Francesco Borromini, plan of the rotunda in the Horti Liciniani (Minerva Medica), 12.11.1643, pencil on paper

unprecedented design allowed Borromini to build an enormous cupola, one that completely dominates the courtyard. If he had followed the rule of inscribing his cupola inside the generating figure, like Giuliano da Sangallo or Peruzzi, it would have been a mere 72 palmi in diameter (clear interior width). Della Porta's cupola would in fact have been larger, having 86 palmi of clear interior width, and 96 palmi on the exterior. This was the maximum that any conventional design could provide without impinging on the corridor vaults. But in Borromini's church the interior span is as large as 92 palmi, while the exterior diameter is 102 palmi when measured diagonally from apse to apse. This is why Borromini's drum looms so large in the courtyard. Its power comes not only from shape but also from size.

If a Renaissance architect might have designed the cupola of S. Ivo differently, so too would a late baroque designer. Nurtured on the example of S. Ivo, architects like Ferdinando Sanfelice or Jan Santini-Aichel, the great geometrical masters of the eighteenth century, were naturally drawn to plans full of sharp angles, often based on stars. ${ }^{46}$ But they always saw to it that the star-shaped interior was reflected directly on the exterior, in the form of angular and multifaceted drums and cupolas. This does not happen at S. Ivo. Borromini fixed his eye steadily on the example of antiquity, particularly on the great apsidal rotundas in and outside of Rome. Minerva Medica and its progeny were decisive in shaping the cupola of S. Ivo.

On the back of a document dated 12 February 1643 Borromini sketched the plan of Minerva Medica [Figure 15]. ${ }^{47}$ This drawing shows him looking firsthand at a building which
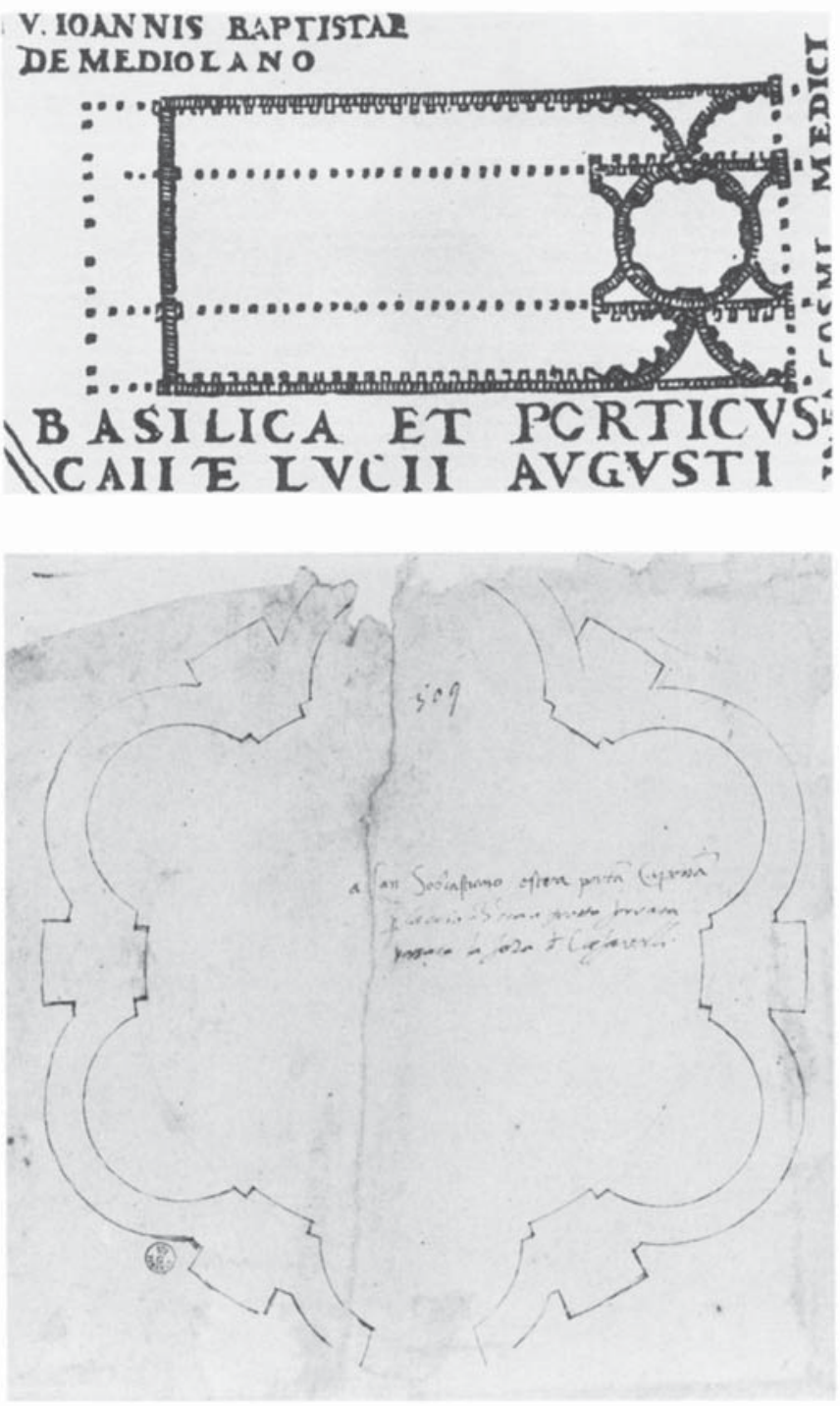

FIGURE 16: L. Bufalini, plan of the rotunda in the Horti Liciniani, 1551, woodcut

FIGURE 17: Baldassarre Peruzzi, "Mausoleum of the Calventii," plan, ink on paper, Uffizi I 651 Ar $(24.4 \times 25.6 \mathrm{~cm})$

he also knew from the antiquarians, such as Giuliano da Sangallo or Giovanni Battista Montano. ${ }^{48}$ If he needed an example of a Minerva Medica inside a larger rectangular building, he could look to the Bufalini map of Rome of 1551, where it is put at the end of the Basilica of Caius and Lucius [Figure 16]. ${ }^{49}$

But the ancient rotunda that most influenced S. Ivo was the so-called Mausoleum of the Calventii near the Via Appia, a late fourth- or early fifth-century Christian "hexaconque funéraire" with six apses in brick-faced concrete ${ }^{50}$ It had been drawn by many antiquarians, including Fra Giocondo, Peruzzi, Serlio, Palladio, Montano, and the author of the Kassel Codex. It was and is still standing, but nevertheless Borromini seems to have relied heavily on the antiquarian tradition, especially, once again, on plans by Peruzzi [Figures 17 and 18]. ${ }^{51}$ For in the actual ruin the buttresses that rise up to support the cupola are 
absorbed into the structure between the apses, and do not protrude so markedly as they do on Peruzzi's plan and in the drum of S. Ivo. ${ }^{52}$ The "hexaconque funéraire" was a static, additive structure, but Peruzzi's drawing stimulated Borromini into thinking of it in more dynamic terms. In the end the drum of S. Ivo is all apses with no central cylinder. They bulge out like sacks of water under high pressure, held back by the powerful inward push of the pilaster clusters that act as buttresses between them. ${ }^{53}$

Rome researched on the site, and in the school of all the antiquarians is the title of a guidebook by Borromini's friend Fioravante Martinelli, but it also is a good description of Borromini's strategy for fruitful research. ${ }^{54}$ But even with his head full of ideas measured on the ground or found in the great mass of antiquarian drawings floating around Rome, Borromini's was still a combinatory, agile mind that went beyond imitation to something funadamentally new. He took well-known exempla from the antiquarian or the Renaissance traditions but subjected them to a new geometrical discipline and changed them in unexpected ways. In the case of S. Ivo we can identify his sources and chart their transformation step by step, though in the end we would never have been able to predict the combinations to which they were subjected by an imaginative mind.

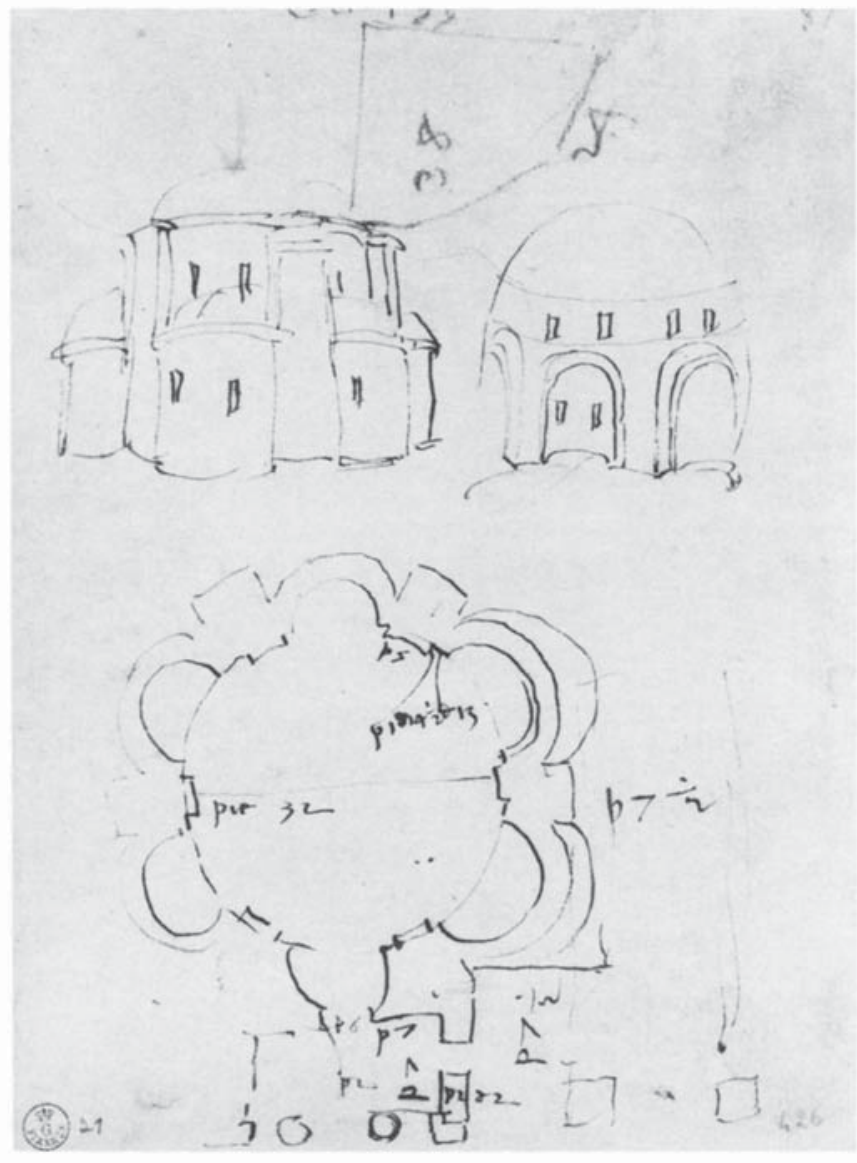

FIGURE 18: Baldassarre Peruzzi, "Mausoleum of the Calventii," plan, elevation, and section, ink on paper, Florence, Uffizi $426 \mathrm{Ar}(21.6 \times 15.8 \mathrm{~cm})$

\section{NON-SOURCES}

The thrust of the argument thus far is that one can arrive at the plan of S. Ivo through transformations of purely architectural material. Geometry of course is a highly visible part of Borromini's design process, and he felt obliged to include at least one explicitly iconographical motif, the seven-column exedra over the altar. But it is possible to arrive at the plan of $\mathrm{S}$. Ivo quite easily without recourse to zoomorphic, emblematic or cabalistic sources. Neither the bee nor the star of Solomon play any role at S. Ivo. ${ }^{55}$

The bee of the Baberini coat of arms was of course important in the rhetoric, both visual and verbal, surrounding the commission. ${ }^{56}$ At the center of the ASR drawing, as a device to make it more attractive to the Barberini, Borromini drew six bees radiating from a sun which, with its eyebrows and puckered mouth, exudes personality even on this minuscule scale. The well-known bee print that appeared in Giannini's Opera in 1720 seems to preserve an early Borromini plan [Figure 19] ${ }^{57} \mathrm{It}$ may suggest a pavement pattern or, as Maurizio Fagiolo and John Scott think, the decoration of the vault of the lantern. ${ }^{58}$ Scott in particular has documented the "apimania" which flourished during the Barberini pontificate and provided the theme for numerous treatises and panegyrics. In the world of Francesco Stelluti's Melissographia (1625) and Leone Allacci's

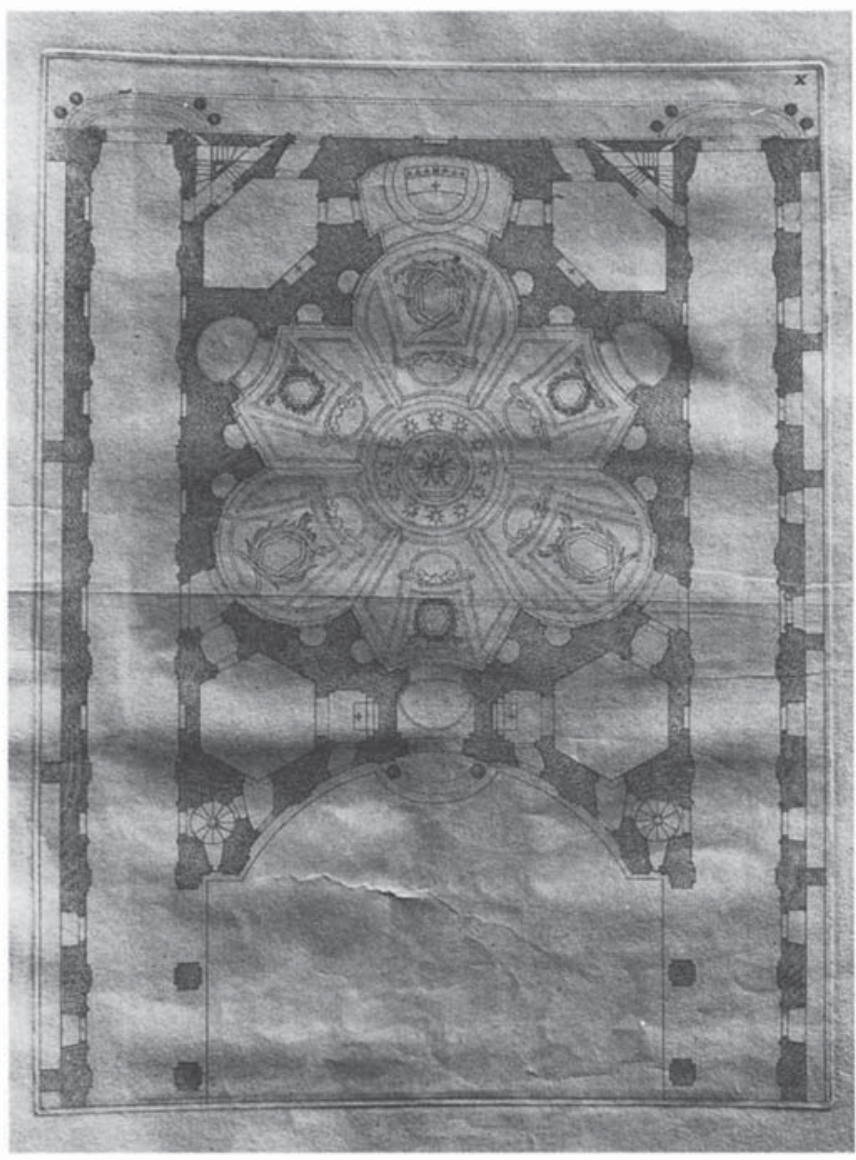

FIGURE 19: Sebastiano Giannini after Borromini, S. Ivo, bee plan, 1720, etching 
Apes Urbanae (1633) it probably occurred to many courtiers, eventually to Borromini himself, to justify this strange, polylobed plan in terms of the heraldic bee. Every Barberini enterprise was cradled in the dry tinder of courtly panegyric, which the spark of flattery could easily set ablaze. Once the comparison was made it easily stuck, and remained alive in people's minds long beyond the Barberini period. In 1661 the polygraph Macedo could refer to the plan as being designed in the shape of a flying bee, ${ }^{59}$ and Carlo Cartari could say more cautiously after Borromini's death, "Nella fabrica della chiesa, che si principiò in tempo di Urbano Ottavo, e perciò è quasi in forma d'Ape..." (In the building of the church, which was begun in the time of Urban VIII, and thus is almost in the shape of a bee....) ${ }^{60}$

But a rhetorical gloss should not be confused with an architectural source. The church was designed by absorbing and transforming antique rotundas and plans from Peruzzi and Giuliano da Sangallo, not by imitating the shape of a bee. Even in its most schematic form a convincing bee plan would have to have four rounded spaces corresponding to the wings, two on each side, and two angled spaces opposite each other corresponding to the head and sting. The Peruzzian alternation of three lobed and three angled spaces is quite different.

Furthermore, it is easy to forget what a liability the bee became after 1644. Innocent $\mathrm{X}$ at first turned his back on a church that was full of Barberini associations and could not be lured into the patronage of $\mathrm{S}$. Ivo for the greater part of his pontificate. His unique contribution, the lantern, was covered with Pamphilj heraldry. The dove on the exterior was meant to allude to his family, while that on the interior of the lantern was "the Holy Spirit, who brings true wisdom." ${ }^{61}$ We may wonder if this revealing phrase in the misure was not really half of an unfinished sentence, the unwritten part being "and drives out the Godless bee." Although Urban VIII's heraldry was allowed to remain on the exterior of the south classroom wing, no bees survive in the area of the church proper. ${ }^{62}$

Under Alexander VII the bee was embarrassing for another reason. The classical taste of the pope and of his leading architect, Bernini, exalted regular geometrical figures such as the circle and its derivative the oval, the square, the hexagon, and the octagon. Bernini, like Archimedes, thanked the gods for the circle and the compass with which the circle is made. ${ }^{63}$ His church in Ariccia, which is a pure circle in plan, seems like a studied criticism of the polylobed plan of S. Ivo.

In this colder climate of the 1660 s Martinelli came to Borromini's defense by redefining the bee as a perfect geometrical figure, making it equivalent to the hexagon:

[The plan] is based on the papal device of the Barberini bee, which, with its head and its four outspread wings, forms a hexagonal figure, numbered among the most perfect by architectural authorities [Borromi- ni's half-legible marginal note: whence the compass is called a "sesto," since with a single fixed opening it embraces its diameter (read radius), repeated six times in its circumference], and this is exactly what the angular site needed. ${ }^{64}$

Borromini's marginal note strengthens Martinelli's defense by observing that the hexagon and its circumferent circle can be formed with a single opening of the compass. ${ }^{65}$ The hexagon, however faint it might be on the ASR drawing, and however invisible it was in the church itself, would save the design from the new classicizing criticism. It was at this time that the marble floor was laid out with an emphatic hexagon around the perimeter. ${ }^{66}$

The second oft-cited source that does not seem to have played any role in the genesis of the church is the star of Solomon, made up of two interpenetrating equilateral triangles. ${ }^{67}$ It appears on none of Borromini's own plans, and even in the first two decades of the eighteenth century draftsmen of the caliber of Filippo Juvarra or Johann Conrad Schlaun still used the single triangle in the construction of the plan. ${ }^{68}$

The double triangle first appears in a print in Giannini's Opera of 1720 [Figure 20]. ${ }^{69}$ Unlike the bee print in the same publication, it gives every indication of being an eighteenthcentury concoction. The large double-page format excludes an origin among the plates etched for Borromini in 1660 by Barrière, while it is typical of Giannini's own additions to the volume. Giannini indeed had authentic Borromini drawings in front of him, but they are the well-known set in the Albertina, Alb. 499-500. He took over the basic geometry from them but added a second triangle. It is superfluous in a constructional sense, giving no key points on the plan. ${ }^{70}$ But it answered a felt need and immediately influenced the eighteenth-century perception of the church. For example, an inventory of 1727 that mentions the pavement interprets it in terms of two triangles: "lastricato di marmo bianco e turchino à scacchi, che ogni due pezzi formano un'esagona, essendo la pianta di essa [chiesa] due triangoli, uno dentro l'altro" (paved in a checkered pattern with white and blue marble, where each pair of pieces forms a hexagon, since the plan of the church is two triangles, one within the other) ${ }^{71}$

Once introduced, the double triangle proved tenacious, and the church is still often seen through this eighteenth-century filter.

\section{Courtly Geometry}

The church was in construction only nineteen months before Urban VIII's death on 29 July 1644 . These were terrible times, when Rome was rent by the War of Castro and the final humiliating defeat of the papal forces. ${ }^{72}$ The enceinte around the Janiculum, not $\mathrm{S}$. Ivo, was the major building project of the end of the pontificate. On 12 September 1644, while the 


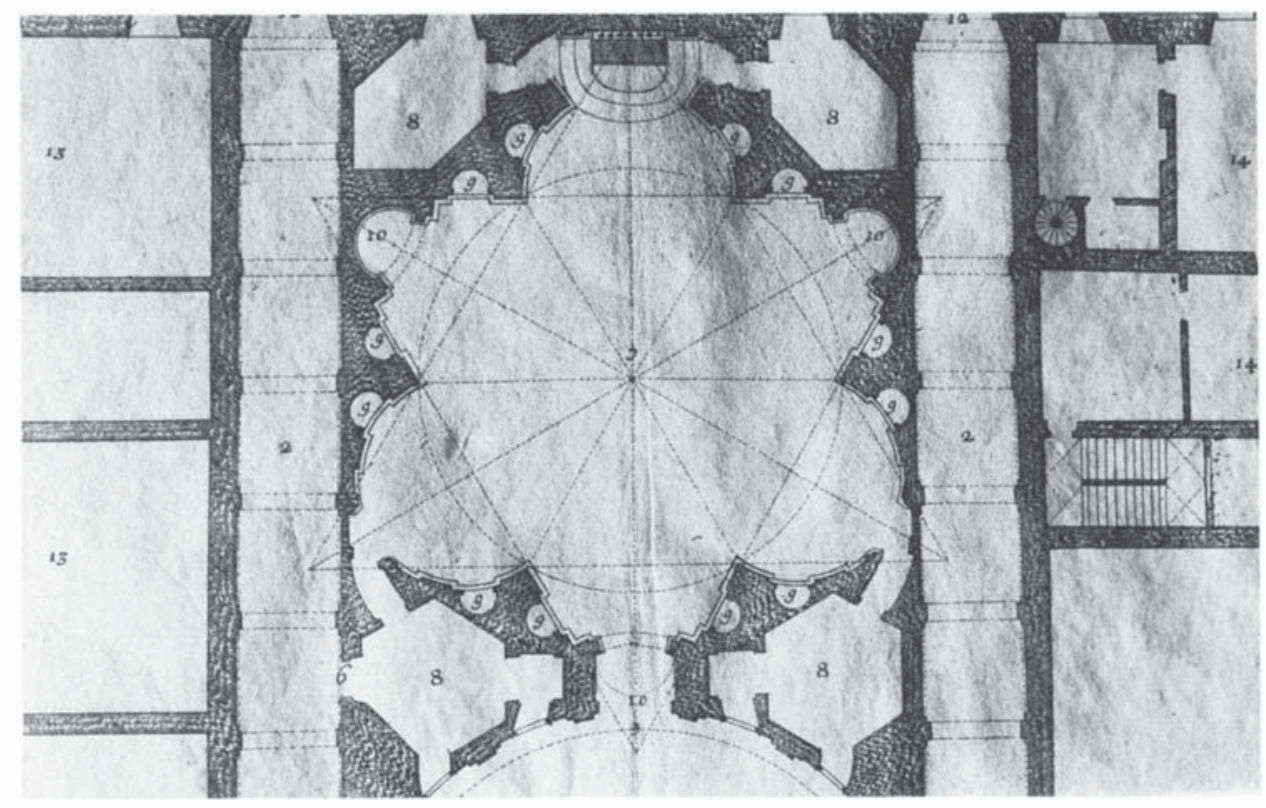

FIGURE 20: Sebastiano Giannini, S. Ivo, star plan, 1720, etching

conclave was still in session, the masons signed a contract binding themselves to finish the cupola of S. Ivo by October. ${ }^{73}$ Three days later Innocent $X$ was elected pope. Thus the cupola, with no superstructure, was finished during the first weeks of Innocent X's pontificate but not on his initiative. The shell of the church in rustica, different in so many small ways from the present church, stood relatively untouched for the next seven years, a Barberini orphan in a world turned hostile.

In the early 1640s Borromini had begun collecting a small dossier on Hagia Sophia, the great Wisdom dedication, and on S. Vitale in Ravenna, which was interpreted as its reflection. ${ }^{74}$ In the end neither church influenced the form of S. Ivo as much as Peruzzi's drawings and the ancient apsidal structures to be found in Rome itself or in the immediate vicinity. But what makes S. Ivo fundamentally different from any of the "tempietti" in Giovanni Battista Montano or in Francesco Barberini's survey of Hadrian's villa is its insistent geometry, and this may be clarified to some extent by focusing on the man who gave Borromini some drawings after S. Vitale. ${ }^{75} \mathrm{He}$ is Fra Benedetto Castelli (1578-1643), a Benedictine of the Congregazione Casinense di S. Giustina, based in Rome at S. Paolo fuori le mura and S. Callisto in Trastevere. ${ }^{76}$

Castelli entered the Benedictines in 1594, and in 1604 he became Galileo's student in Padua. ${ }^{77}$ They would remain lifelong friends and correspondents, and hundreds of letters between the two scientists have been preserved. Galileo's Letter to the Grandduchess Christina of 1615 began as a letter to Castelli. His achievement in mathematics and astronomy was considerable. Along with Kepler, who first observed the hexagonal shape of snowflakes, he investigated what would now be called "close packing" in his study of the hexagonal shape of the paving stones on Roman roads. ${ }^{78}$ But his real fame was as a hydrologist. Inventor of the concept of velocity of flow, he considered the secrets of rivers and seas as abstruse as those of the stars and planets. In 1624 Urban VIII called him to Rome as a consultant in water control for the Papal State and tutor in mathematics for the young Taddeo Barberini, to whom he dedicated a book on hydraulics in $1628 .{ }^{79}$ Francesco Barberini had him appointed reader in mathematics at the Sapienza in 1627 , a post which he retained until his death on 19 April 1643 , even though after 1632 he wanted nothing more than to retire to Florence to attend his aging master in the confinement of Arcetri. $^{80}$

In a letter that Castelli sent to Galileo in 1631 we get a glimpse of how fashionable the study of geometry became in the upper layers of the Barberini court. He writes from Pesaro, where the court was sojourning while Cardinal Antonio Barberini supervised the transfer of the vacant duchy of Urbino to the Papal State. He remarks with wry amusement on the gay times had by the many knights and gentlefolk in the cardinal's entourage, while he devoted himself instead to the solution of hundreds of equations. One day he was approached by a group of literate gentlemen who wanted to be taught the principles of geometry. Some of these dilettantes he found to be unusually intelligent. But when he recounted the merits of Galileo's work they were at first stunned, and were "most contrary to your name and your work, of which either they knew nothing at all or which they had learned in a distorted fashion. But now they are studying away with gusto." ${ }^{81}$

Castelli was the professor of mathematics at the Sapienza when Borromini designed S. Ivo. Thus, directly or indirectlyeither as professor, or as the man who set the geometrical fashions of the Barberini court, or as the friend who vicariously visited S. Vitale when the architect could not-he was a 
member of the public for whom the drawing we have been studying was designed. Castelli's successor in the chair of mathematics at the Sapienza in 1643 was another Galilean, the young Gaspare Berti, who also knew Borromini and once even made a model for the architect. ${ }^{82}$ Geometry may well have been part of the intellectual baggage that Borromini brought with him from the cathedral workshop of Milan, but we should not neglect the Roman public whose attention it had to catch. ${ }^{83}$ Gentlemen's geometry, pursued as a demanding pastime, deriving from innovative science but innocent of its dangers, easily fused with the cult of antiquity and the allegorical use of heraldry so deeply engrained in Barberini culture: this is what seems to be shown on the ASR plan of S. Ivo.

\section{ConClusion}

Let us return to the question of what went on in "the first three minutes." Even if the light does not yet shine directly on the creative moment, it has still been possible to marshal the evidence in such a way as to close in on it from both ends. Before the moment itself we have the problem: the tiny and irregular site, the mixture of straight walls and curved screen, the lack of direct light on both sides for the first 60 feet off the ground. Borromini relished the problem in all its knottiness, "knowing that the true test of the architect's worth lay in the difficulties, by which he was assailed, by which his genius was given scope." Martinelli's words allow us to imagine something of the architect's state of mind as he picked up the pencil. ${ }^{84}$

After the great idea had come, we have the detailed and informative evidence of the ASR drawing with its two main phases and its many smaller adjustments. We can see the architect using a geometrical figure as a moving template, subdividing it with the compass but then also designing by eye, deepening the niches and working out the proportions of a very tall building with every move on the plan, adding a seven-column exedra for the altar, then revising it from a broad arc to a horseshoe, then adding extra property at the back of the church to accomodate the changes. This process of working out the design would go on, with many fundamental changes, over the next two pontificates.

But how much can we meaningfully say of the creative flash itself? Any correctly identified source helps to fill the silence: "A Peruzzian triangle would fit the site perfectly." "The seven columns of Proverbs 9 would be awkward in the church but can go on the altar." "The cupola could be given great presence if it were circumscribed around the plan, not confined within it." "The ancient hexaconch on Via Appia could make a powerful drum, even though only half its lobes will sit easily on the basic plan." "The eggshell will hold up well enough so long as it is never overloaded with a heavy lantern."

Beyond this point we run up against the perennial question: How much can the anticipated reception of a work of art be said to influence its creation? Like asking how far upstream a salt tide rises, the answer will be a matter of calibration; it depends on the strength of the current, the height of the tide, and the sensitivity of the drinker. It is not hard to imagine Borromini pausing to think of the connoisseurs in the Barberini court, like Cassiano Dal Pozzo and Cardinal Francesco Barberini himself. These men would see the range of ancient and Renaissance sources he could conjure up, admire the ways he combined them, and note the skill with which he departed from them. But Borromini had frequented the Barberini palace too long not to know its army of sycophants and panegyrists, literary men with endless resources in the arts of flattery. To them he could always throw the bee. The court had also known dilettantes of architecture, like the advisors on the palace program or like Orazio Busini, a well-traveled courtier who had tried to catch Taddeo Barberini's eye with an unusual architectural print in 1631. It showed a palace, banal enough in itself, but transformed by geometrical diagrams into an "Instrument of Numerical Wisdom." 85 Borromini may have found these people useful; it is unlikely he would have found them deep.

$\mathrm{S}$. Ivo is a highly geometrical church, the very walls of which would always seem to be in motion. Of all the possible publics that might have been in Borromini's mind one wants especially to remember Benedetto Castelli, the knot of Barberini gentlemen the good Benedictine had schooled in geometry, the younger mathematicians in court and university circles, and the older survivors from the first Accademia dei Lincei, in short, a small core of people who had felt the appeal of Galileo's dictum that the great book of nature was written in the language of mathematics. $^{86}$

\footnotetext{
Notes

My thanks to Henry Millon for starting me on the problem, and to John Pinto, John Beldon Scott, and Elisabeth Kieven for conversations in and on S. Ivo between 1972 and the present. I am grateful to the Director of the Archivio di Stato in Rome, Lucio Lume, and to his staff for many courtesies, especially Donato Tamblé and Aldo Mastroianni, and also to Richard Bösel and Veronika Birke of the Albertina in Vienna. I am grateful to Adrienne Atwell for her excellent drawings, and to Sabine Eiche for obtaining unobtainable photographs. A conversation with Prof. and Frau Heinrich Thelen as the article was going to press was illuminating on a wide range of Borromini problems. My thanks to Richard Hodges of the British School at Rome for an invitation to lecture on S. Ivo in 1988, and also to receptive audiences at Rensselaer, The Courtauld Institute, the Architectural Association in London, Cornell, the University of Pennsylvania, Notre Dame, and the Harvard Graduate School of Design. Research was supported in 1986-1987 by the Guggenheim Foundation and the American Academy in Rome, in 1994-1995 by the NEH, and throughout by Columbia University, and I am deeply grateful to all of them.

1 The documentary thesis by Elisabetta Cirielli and Alessandra Marino ("Il complesso della Sapienza: lettura critica dei documenti d'archivio e loro riscontro sul manufatto ai fini della conservazione," Università degli Studi di Roma, Facoltà di Architettura, 1981-1982, copy in the Bibliotheca Hertziana) has been summarized in the article by the same authors: "Il complesso della Sapienza: le fasi del cantiere, gli interventi successivi al Borromini, le manutenzioni," Ricerche di Storia dell'Arte 20 (1983): 39-64. Citations below are from the article rather than the thesis, but I have transcribed the documents directly from the originals in the Archivio di Stato in Rome. Still useful is an earlier article on
} 
the restorations: Riccardo Pacini, "Alterazioni dei monumenti borrominiani e prospettive di restauro," Studi sul Borromini (1967) (Rome, 1970-1972), I: $317-341$, especially $332-336$. To summarize the major changes under Alexander VII: in the upper reaches of the interior walls twelve niches and two large windows were filled up, two corretti were opened up in the same area, the high altar and its light sources were reconfigured to allow light to enter from three hidden sources, and two large side doors were sealed and replaced by the present double doors. In addition, the vault stuccoes, full of Chigi heraldry, were carried out; the double-clustered pilasters on the exterior of the drum were replaced with triple-clustered pilasters; and the drum ornament was altered with the introduction of the Chi-rho disks over the windows and the Sapienza symbols from Ripa. Also, the east façade of the building was lowered to expose the drum to the view from Piazza S. Eustachio (Maurizio Fagiolo, "La Sapienza di Borromini: un progetto per il Palazzo dell'Università; l'emblematica / la natura / la struttura significante," Storia dell'Arte 38/40 [1980]: 343-351).

${ }^{2} \mathrm{I}$ argue this point in a companion article on Innocent $\mathrm{X}$ 's spiral, forthcoming in Burlington Magazine.

${ }^{3}$ Under the Barberini the church was simply called the chapel of the Sapienza. S. Ivo, the lawyer saint, possibly entered the dedication under the next pope, Innocent X, who was himself a lawyer. But the move of the cult from the small Breton church of S. Ivo near the Via della Scrofa (Nolli 504) to the chapel of the Sapienza is documented only from the time of the next pope, Alexander VII. Even so Borromini's church was called by a variety of names for many years afterwards: Santi Fortunato e Leone nella Sapienza (Giovanni Battista Falda, Il nuovo teatro delle fabbriche, 3 vols. [Rome, 1665-1667], I: pls. 19, 20); S. Leon de la Sapience (M. Huguetan, Voyage d'Italie curieux et nouveau [Lyons, 1681], 301); $\mathrm{S}$. Leon le grand (François Deseine, Description de la ville de Rome, 3 vols. [Lyon, 1690], 2: 227); S. Luca (Giuseppe Vasi, Delle Magnificenze di Roma antica e moderna, 10 vols. [Rome, 1747-1761], 4: pl. 70). S. Ivo elbowed his competitors out only in the latter half of the eighteenth century.

The bibliography on S. Ivo alla Scrofa includes B. Pocquet du Haut-Jussé, "La compagnie de Saint-Yves des Bretons à Rome," Mélanges d'archéologie et d'histoire de l'Ecole Française de Rome 37 (1918-1919): 201-283; François Macé de Lépinay, "Architecture religieuse à Rome à la fin du XIXe siècle: la reconstruction de Saint-Yves-des-Bretons," in Les fondations nationales dans la Rome pontificale, Collection de l'Ecole Française de Rome, 52 (Rome, 1981), 423-451; unpublished façade drawing by P. Coccetti, Albertina 531

4 " $[\mathrm{L}] \mathrm{a}$ muraglia per di fuori è formata con sei semicircoli a guisa d'una rosa di sei foglie," in ASR, Fondo Università, vol. 115, fol. 403r (henceforth the location of documents from this source will be abbreviated in the following format: ASR U 115.403r); cited by Elisabeth Kieven, Von Bernini bis Piranesi. Römische Architekturzeichmungen des Barock (Stuttgart: Graphische Sammlung Staatsgalerie, 1993), 74.

${ }^{5}$ Gian Giacomo de Rossi, Insignium Romae Templorum Prospectus (Rome, 2nd ed., 1684), pl. 42; reproduced in Daria de Bernardi Ferrero, L'opera di Francesco Borromini nella letteratura artistica e nelle incisioni dell'età barocca (Turin, 1967), pl. 34.

${ }^{6}$ SS. Cosma e Damiano annexed to the monastery of S. Chiara, designed by Giuseppe Mariani (1681-1731) of Pistoia, a member of the Order of the Crociferi, in 1721. Mariani studied in Rome in 1704 while residing at the order's mother house at S. Maria Maddalena. His other well-known work, the cupola of S. Giuseppe dei Teatini in Palermo of 1725, also followed a Roman model, the cupola of S. Andrea della Valle by Maderno. See Vincenzo Scuderi, "L'architetto pistoiese Giuseppe Mariani (1681-1731) e le sue opere siciliane," Commentari 11 (1960): 260-264; Salvatore Boscarino, Sicilia barocca (Rome, 1981), 129; and Wolfgang Krönig, Sizilien (Darmstadt, 1986), 104 and pl. 15.

${ }^{7}$ Julia Smyth-Pinney, "Borromini's S. Ivo: Perception and Plans," ARRIS 5 (1994): 45, makes the interesting point that it is difficult or impossible to take in the wide-angle view even when lying down on the floor of the church.

${ }^{8}$ For the publication enterprise of 1660 see Joseph Connors, Borromini and the Roman Oratory (New York and Cambridge, Mass., 1980), 263-269 (cat. 89-90); 281-282 (cat. 104); 285-288 (cat. 110); idem, "Sebastiano Giannini: Opus Architectonicum," in Bruno Contardi and Giovanna Curcio, eds., In Urbe Architectus: modelli disegni misure: La professione dell'architetto in Rome 1680-1750 (Rome, Castel S. Angelo, 1991), 207-209. Borromini's nephew kept Barrière's etched plates but seems never to have made them public. Proofs entered the collection of Carlo Antonio Dal Pozzo and can be found today in the British Library. De Rossi seems to have had access to them for his 1684 publication, but for some reason did not find a copy of the "pianta giumetrale" that Barrière supposedly made, hence his atrocious plan. On the other hand, C. Pericoli Ridolfini (in Marcello Del Piazzo, Ragguagli borrominiani [Rome, 1968], 153) proposes that the De Rossi plan preserves an early project by Borromini.

${ }^{9}$ ASR, Università, vol. 198 , no. 122 , formerly inserted into the volume in a position corresponding to 1655 but clearly dating earlier, removed for conservation in 1989 and now kept separately. Bibliography includes Oskar Pollak, Die Kunsttätigkeit unter Urban VIII., 2 vols. (Vienna 1928), 1: 161, reg. 507; Antonio Muñoz, "Il Palazzo e la chiesa della Sapienza," L'Urbe 2.2, fasc. 10 (1937): pl. IX (first photograph); Leonardo Benevolo, "Il tema geometrico di S. Ivo alla Sapienza," Quadermi dell'Istituto di Storia dell'Architettura dell'Università di Roma 3 (1953): 8-10; idem, "Il problema dei pavimenti borrominiani in bianco e nero," Quaderni dell'Istituto di Storia dell'Architettura dell'Università di Roma 13 (1956): 9-12; Paolo Portoghesi, "Saggi sul Borromini. III.-La vita di Borromini," Quaderni dell'Istituto di Storia dell'Architettura dell'Università di Roma 27/29 (1958): 19; idem, Borromini nella cultura europea (Rome, 1964), pl. 58; Hans Ost, "Borrominis römische Universitätskirche S. Ivo alla Sapienza," Zeitschrift für Kunstgeschichte 30 (1967): 109, fig. 9; Marcello Del Piazzo, Ragguagli borrominiani (Rome, 1968), 152-153; Pierre de la Ruffinière du Prey, "Solomonic Symbolism in Borromini's Church of S. Ivo alla Sapienza," Zeitschrift für Kunstgeschichte 31 (1968): 216-232, revised as "Revisiting the Solomonic Symbolism of Borromini's Church of Sant'Ivo alla Sapienza," Volume Zero (The Rensselaer Polytechnic Institute Architectural Journal) (1986): 59, fig. 2; Eugenio Battisti, "Il simbolismo in Borromini," Studi sul Borromini (1967), 2 vols. (Rome, 1970-1972), 1: fig. 23; Marcello Fagiolo, "Sant'Ivo, 'Domus Sapientiae'," ibid., 2: 151 and fig. 6; Anthony Blunt, Borromini (London, 1979), 114-115; Maurizio Fagiolo, "La Sapienza di Borromini: un progetto per il Palazzo dell'Università; l'emblematica / la natura / la struttura significante," Storia dell'Arte 38/40 (1980): 349-351; John Beldon Scott, "S. Ivo alla Sapienza and Borromini's Symbolic Language," JSAH 41 (1982): 296, fig. 3; Aldo Mastroianni, "Il Borromini alla Sapienza," in Paolo Cherubini, ed., Roma e lo Studium Urbis. Spazio urbano e cultura dal quattro al seicento (Rome, Archivio di Stato, 1989), cover and color detail on p. 89 (this publication is not to be confused with the acts of the convegno of 1989, published with the identical title in 1992 and cited in n. 13 below); Kieven, Von Bernini bis Piranesi, 67-69; Martin Raspe, Das Architektursystem Borrominis (Munich, 1994), 105-106 and figs. 42-43; Smyth-Pinney, "Borromini's S. Ivo," 51, fig. 17. The forthcoming volume of the corpus of Borromini drawings by Heinrich Thelen will treat all projects begun under Urban VIII, and will include the definitive publication of the ASR drawing.

${ }^{10}$ Modena, Biblioteca Estense, Collezione Campori, piante e disegni, $\gamma$ I.I.50, fol. 14r-v, first published in Jack Wasserman, "Giacomo della Porta's Church for the Sapienza in Rome and Other Matters Relating to the Palace," Art Bulletin 46 (1964): 501-510, and often reproduced. There is an especially fine treatment in Michael Kiene, "Der Palazzo della Sapienza-Zur Italienischen Universitätsarchitektur des 15. und 16. Jahrhunderts," Römisches Jahrtruch für Kunstgeschichte 23/24 (1988): 251-259, figs. 27, 29, 32, 33, 37; Kiene puts the drawing into the larger context of Italian university architecture. The dimensions of the drawing are $56.9 \times 43.7 \mathrm{~cm}$, and of the Sapienza itself, $54.7 \times 36.1 \mathrm{~cm}$. There are two scales: recto (with the plan of Sapienza), $100 \mathrm{p} .=14.6 \mathrm{~cm}$. (1:153); verso (with the details), $50 \mathrm{p} .=12.3 \mathrm{~cm}$. (1:90). My thanks to Massimo Bulgarelli for assistance in finding the drawing in Modena, and to Alice Jarrard for helpful observations.

"For example, the plan shows six windows on the ground floor of the west façade of the Sapienza, even though in the final building there were windows only on the piano nobile. It shows a shallower exedra than the one built, with a radius of 56 palmi, as opposed to the 47 palmi that we find on Borromini's and other later plans. The two long corridors flanking the church do not emerge directly onto the Piazza S. Eustachio but empty into small closed spaces marked "cortile scoperto," which seem to serve both as vestibules and as light wells for the high altar chapel. The plan takes no account of the difference in ground level between the courtyard and Piazza S. Eustachio (about .75 meters on the north and .65 meters on the south). The slope is reflected in a later drawing by Domenico Castelli (Kiene, "Palazzo della Sapienza," 258, fig. 35), and was eventually accomodated by Borromini in various ways. At first he thought of putting semicircular cordonate outside of the two eastern doors (shown on a print of 1660 by Domenico Barrière in Sebastiano Giannini, Opera del Cav. Francesco Boromino, 2 vols. [Rome, 1720-1725), 1: pl. V). The cordonata on the north was built (ASR U 109.115v) but later removed, and now a set of steps can be found just inside the portal. Since the narrowness of the street prevented the south 
cordonata from being built, Borromini at first thought that the south portal would have to be blind ("li due portoni uno reale, e l'altro finto," ASR U 114.381r; "il Porton finto della strada verso Lanti," ASR U 114.357r). But the final solution was an open portal with a sloping corridor ("per abbassar il piano di detto portico in declivio per accompagnar l'entrata verso Lanti," ASR U 198.25v-26r).

${ }^{12}$ Among the few published measurements of S. Ivo are those in Luciano di Sopra et al., "Sant'Ivo alla Sapienza, di Francesco Borromini," L'Architettura Cromache e Storia 3 (September 1957): 342. I repeat them here, adding the dimensions in palmi by applying the standard equivalent of 1 palmo romano $=$ $.2234 \mathrm{~m}$ :

$1931 / 3$ palmi $=43.20 \mathrm{~m}$ : height of flaming stone crown

$164 \mathrm{y} / 4$ palmi $=36.80 \mathrm{~m}$ : height of lantern vault on interior

132 palmi $=29.50 \mathrm{~m}$ : height of lantern ring

$1092 / \mathrm{spalmi}=24.50 \mathrm{~m}$ : height of top of drum on exterior

77 palmi $=17.20 \mathrm{~m}$ : height of the rib bases on the interior of the dome

$58 \% 3$ palmi $=13.10 \mathrm{~m}$ : height of loggia scoperta

${ }^{13}$ Heinrich Thelen, "Der Palazzo della Sapienza in Rom," in Miscellanea Bibliothecae Hertzianae zu Ehren von Leo Bruhns, Franz Graf Wolff Metternich, Ludwig Schudt (Munich, 1961), 285-307; Kiene, "Palazzo della Sapienza," 241-262; Robert Stalla, "Der römische Palazzo della Sapienza als 'Gymnasion.' Ein Hauptwerk Pirro Ligorios_-Planung und Zuschreibungsfrage," An Architectural Progress in the Renaissance and Baroque. Essays in Architectural History Presented to Hellmut Hager on His Sixty-sixth Birthday, ed. Henry Millon and Susan Scott Munshower (University Park, 1992), 112-145; Manfredo Tafuri, Ricerca del rinascimento. Principi, città, architetti (Turin, 1992), 101; Fioravante Martinelli, Roma omata dall'architettura, pittura $e$ scoltura, MS 4984 of the Biblioteca Casanatense in Rome (1660-1663), in Cesare D'Onofrio, ed., Roma nel Seicento (Florence, 1969), 212 and 216 (this edition is cited hereafter as MartinelliD'Onofrio, Roma); Anna Bedon, "La fabbrica della Sapienza da Alessandro VI alla fine del Cinquecento," Roma e lo Studium Urbis. Spazio urbano e cultura dal Quattro al Seicento (1989) (Rome, 1992), 471-485; and idem, Il Palazzo della Sapienza di Roma (Rome, 1991).

${ }^{14}$ G. Giovannoni, "Il Palazzo Carpegna nuova sede dell'Accademia," La Reale Insigne Accademia di San Luca nella inaugurazione della sua nuoza sede (Rome, 1934), 35-107; red chalk is used on Alb. 1009a, 1009e, 1010, 1011, 1014, $1014 \mathrm{a}, 1014 \mathrm{~b}, 1015,1017 \mathrm{a}$. It is also found in several early drawings in the Borromini corpus by Heinrich Thelen (Francesco Borromimi. Die Handzeichnungen. 1. Abteilung. Zeitraum von 1620/32 [Graz, 1967], C38 of 1628 and C56r\&v of 1631 , as well as on the famous first plan of S. Carlo alle Quattro Fontane of 1634 Alb. 171, but only to show the upper floors of the dormitory wing. The red chalk site plan of Palazzo Giustiniani, done just before Borromini's campaign of 1650 , seems to me to be by Francesco Righi (ASR, Archivio Giustiniani, busta 10, no. 27/18; see Ilaria Toesca, "Note sulla storia del Palazzo Giustiniani a San Luigi dei Francesi," Bollettino d'Arte 42 (1957): 302, fig. 9). Borromini uses red chalk, very sparingly, as late as 1659 on Alb. 86, a project for Piazza S. Agostino (Eberhard Hempel, Francesco Borromini [Vienna, 1924], 173, fig. 63).

${ }^{15}$ There is a short list of drawings with Roman numeral scales in Connors, Oratory, 205-206; Heinrich Thelen has kindly shown me his more complete list of 47 such drawings, all done between 1635 and 1640, except for the ASR drawing, done in 1642 .

${ }^{16}$ Pollak, Kunsttätigkeit, 1: 160-161, reg. 506; Del Piazzo, Ragguagli, 131.

${ }^{17}$ Thus I have preferred to use the convention of + and - , on the grounds that saying $35+$ (a hair over 35 ) is less misleading than $35 \frac{1}{4}$, and $20-$ (a hair under 20 ) is less misleading than $19 \frac{3}{4}$.

${ }^{18} \mathrm{Alb} .171$, with some of the layers shown on Steinberg, Borromini's San Carlo, 77 , fig. 38. The earliest layers will be shown in detailed architectural renderings in the forthcoming volume of Thelen's Borromini corpus.

19 "[D]oi nicchioni dell'altari minori, o vero dove si metterano statue" (ASR U 198.12).

${ }^{20} \mathrm{~A}$ misura begining on 20.IV.1659 records closing these entrances and replacing them with the present double doors, which give entrance via the sacristies (ASR U 1 15.365v); cf. Cirielli and Marino, "Il complesso della Sapienza," 42.

${ }^{21}$ Cf. the diagram in Scott, "S. Ivo," 299, fig. 8.

${ }^{22}$ Benevolo, "Il tema geometrico," 3, fig. 5; Steinberg, Borromin's San Carlo, 380; and Blunt, Borromini, 115, fig. 83.

${ }^{23}$ Portoghesi, Borromini nella cultura europea, figs. G-I.

${ }^{24}$ See David Summers, Michelangelo and the Language of Art (Princeton, 1981), 368-379, part 2, ch. 10, "Giudizio dell'occhio." Raspe, Architektursystem, 105, gives measurments which, in part, agree with those given here. There is a basic difference of approach, however. He gives 105 palm $i$ as the side of the triangle; I am wary of distortions caused by the crease mentioned above and read 106 palmi. He arrives at all other dimensions by subdividing one of the sides; I think Borromini abandoned subdivision at a certain point and designed the interior membering by eye, using convenient whole numbers.

${ }^{25} \mathrm{I}$ am grateful to the $J S A H$ reader for urging me to think through this issue.

26 "Et avvertasi che in detti nicchi hò voluto più tosto imitare gl'antichi che i moderni dando nell'imboccatura di essi minor larghezza che nel di dentro" (Giannini, Opera, 2: ch. vi, cited from MS C.II.6 of the Archivio della Congregazione dell'Oratorio a S. Maria in Vallicella, Rome, fol. 20r).

${ }^{27}$ The complete inscription reads nel fregio della Porta

SAPIENTIA AEDIFICAVIT SIBI DOMVM Prov. C. 9 nel fregio delle 7 colonne

EXCIDIT COLVMNAS SEPTEM

nel Piedistallo della statua

PROPOSVIT MENSAM SVAM

See the commentary on these verses, which were incorporated into the Byzantine hymnology for Holy Thursday, in John Meyendorff, "Wisdom-Sophia: Contrasting Approaches to a Complex Theme," in W. Tronzo and I. Lavin, eds., Studies on Art and Archeology in Honor of Ernst Kitzinger on His Seventy-Fifth Birthday (Dumbarton Oaks Papers, 41) (Washington, D.C., 1987), 391-401.

${ }^{28}$ M.-Th. d'Alverny, "La sagesse et ses sept filles: recherches sur les allégories de la philosophie et des arts libéraux du IXe au XIIe siècle," Mélanges dédiés à la Mémoire de Félix Grat (Paris, 1946), 1: 245, n. 2; J. Meyendorff, "L'iconographie de la Sagesse divine dans la tradition byzantine," Cahiers Archéologiques 10 (1959): 265, fig. 3, and 273, fig. 8; Ost, "Universitätskirche,"111-114.

${ }^{29}$ Another Peruzzi drawing of interest here is his plan for an oval church with a columnar altar (Uffizi 4137Ar, in Heinrich Wurm, Baldassarre Peruzzi: Architekturzeichnungen [Tübingen, 1984], fig. 367); also relevant is the print after Palladio's plan of the columnar exedras set into the main rotunda of the Baths of Constantine on the Quirinal (Ernest Nash, Pictorial Dictionary of Ancient Rome, 2 vols. [London, 1968], 2: 443, fig. 1243).

${ }^{30}$ In doing this he was overstepping a property boundary that had been fixed as early as 1601-1602, when Maggi founded the southeast corner near Palazzo Stati-Cenci and Palazzo Lante (ASR U 114.45). It seems that this corner is slightly greater than a right angle and that the building is not strictly rectangular but slightly trapezoidal, as shown on the Catasto plan of 1818-1819 in the ASR (sheet VIII.1.2). There is evidence that some older house fronts were incorporated into the east façade in 1659-1660, especially in the area of the northeast portal (ASR U 115.382r-385r). If the eastern property line was fixed, then Borromini's idea of adding 7 palmi to the building was unrealistic.

${ }^{31}$ Karl Noehles, “Architekturprojekte Cortonas," Münchner Jahrbuch der bildenden Kunst 20 (1969): 183-186; Irving Lavin, Bernimi and the Unity of the Visual Arts (New York and London, 1980), 34-35.

${ }^{32}$ Scott, "S. Ivo," 301-302; see also Glanville Downey, "The Name of the Church of St. Sophia in Constantinople," Harvard Theological Review 52 (1959): $37-41$

${ }^{33}$ They are the late Michelangelo Pieta in the ex-Bandini garden on the Quirinal, exported to Florence in 1674, and possibly also the Palestrina Pietà, installed in the Barberini funerary chapel in S. Rosalia in Palestrina in 1677. See Charles de Tolnay, Michelangelo, 5 vols. (Princeton, 1969-1971), 5: 149-153.

${ }^{34}$ To cite a few examples of Sapientia from ecclesiastical contexts: Wilhelm Köhler, Die Karolingischen Miniaturen (Berlin, 1930), 1: 386-388 and pl. 43c (Sapientia in an initial of the Grandval Bible); Giulio Cantalamessa, "Una scultura ignota del Bernini," Bollettino d'Arte 5 (1911): 83 (G. Finelli's tomb of Cardinal Ginnasi in S. Lucia delle Botteghe Oscure, with Charitas and Sapientia); and Luca Giordano's Sapientia Divina on the ceiling of the abbey church at Montecasino (1631, destroyed 1944 but cf. Alinari 12116).

${ }^{35}$ Leo Steinberg, Borromini's San Carlo alle Quattro Fontane: A Study in Multiple Form and Architectural Symbolism (New York and London, 1977), 380-382.

${ }^{36}$ Howard Hibbard, "Scipione Borghese's Garden Palace on the Quirinal," JSAH 23 (1964): 179 and 182, fig. 25.

${ }^{37}$ Uffizi 553Av, first mentioned in the context of S. Ivo by Dagobert Frey, Michelangelo-Studien (Vienna, 1920), 10-11, fig. 1; then Hans Sedlmayr, Die Architektur Borrominis (Munich, 2nd ed., 1939), reprint (Hildesheim and New York, 1973), 70-75; Benevolo, "Il tema geometrico," 4, fig. 8; Portoghesi, 
Borromini nella cultura europea, pl. 55; idem, Borromini: Architettura come linguaggio (Rome and Milan, 1967; 2d ed., 1990), 161 ; Fagiolo, "Domus Sapientiae," fig. 1B; Steinberg, Borromini's San Carlo, 380; Meg Licht, L'edificio a pianta centrale: lo sviluppo del disegno architettonico nel rinascimento, Gabinetto Disegni e Stampe degli Uffizi, 61 (Florence, 1984), 156-157, no. 94; Tafuri, Ricerca del rinascimento, 171 and $211-212, \mathrm{n} .119$. The best illustration is now in Wurm, Baldassarre Peruzzi, fig. 250.

The Peruzzi architectural Nachlass did not enter the Uffizi until the late eighteenth or early nineteenth century; see Lucia Collobi Ragghianti, "Il 'Libro de' Disegni' del Vasari: disegni di architettura," Critica d'arte 20.127 (1973): 3-120; Anna Forlani Tempesti, "Occasione per una traccia sulla provenienza dei disegni architettonici degli Uffizi," in Disegni di fabbriche Brunelleschiane, Gabinetto Disegni e Stampe degli Uffizi, 47 (Florence, 1977), vii-xvii (kind reference of Elisabeth Kieven, who discussed the problem with me at length). That the Peruzzi drawings were in Rome throughout the sixteenth and seventeenth centuries and were somehow available for consultation is the working hypothesis here, shared by Bruce Boucher, "Bernini e l'architettura del cinquecento: la lezione di Baldassare Peruzzi e di Sebastiano Serlio," Bollettino del Centro Internazionale di Studi di Architettura "Andrea Palladio" 23 (1981): 27-43. Occasionally there is a clue to go by, such as Ligorio's remark on a Roman temple, "certamente io no la ho vista ma l'hebbi dalli disegni di Baldassare Peruzzi" (Thomas Ashby, "The Bodleian MS. of Pirro Ligorio," Journal of Roman Studies 9 [1919]: 180); or Antoine Desgodets, Les édifices antiques de Rome (Paris, 1682), 290-291, where he studies the Theater of Marcellus in "un plan très-ancien ... levé par l'architect qui conduisoit le bastiment du Palais qui est présentement à la place de ce Theatre." See also Howard Burns, "Baldassarre Peruzzi and Sixteenth Century Architectural Theory," in Jean Guillaume, ed., Les traités d'architecture de la Renaissance (Paris, 1988): 207-226; and Lionello Puppi, "Il problema dell'eredità di Baldassarre Peruzzi: Jacopo Meleghino, il 'mistero' di Francesco Sanese e Sebastiano Serlio," in Marcello Fagiolo and Maria Luisa Madonna, eds., Baldassarre Peruzzi. Pittura scene e architettura nel Cinquecento (Rome 1987): 491-501

${ }^{38}$ Martin Gosebruch, "Vom Pantheon Vergleichlich-Unvergleichliches. Römische Thermenarchitektur und ihre Auswirkungen auf die Baukunst des Cinquecento," Römische Quartalschrift, 30. Supplementheft (1966): 147-168; and James Ackerman, The Architecture of Michelangelo, 2 vols. (New York, 1961), 1: xxviii.

${ }^{39}$ Christian Hülsen, Il libro di Giuliano da Sangallo codice vaticano barberiniano latino 4424 (Leipzig and Turin, 1910), facsimile (Città del Vaticano, 1984), 48, fol. 32v; another version appears in Sangallo's Siena sketchbook: Rudolfo Falb, Il taccuino senese di Giuliano da San Gallo (Siena, 1902), pl. 19.

${ }^{40}$ The group consists of two drawings and two flaps: Alb. 499 (40.7 x 26.9), plan of the entire Sapienza at ground level; Alb. 500 (37.6 x 26.9), plan of the whole complex at piano nobile and drum level. Alb 500 has two flaps attached, one small flap $(15.5 \times 10.0)$ showing a plan of the church at corretti level, and the other larger flap (17.2 x 26.9) showing the west half of the Sapienza with new dormitory rooms. All three church plans are simplified idealizations of the design, with the generating triangle reduced in size to fit precisely within the space available for the church. The evidence for their late date is as follows. The drawings reflect Alexander VII's new library and other innovations of 1659-60, in particular: large doors in the side apses sealed and replaced with small double doors, niches sealed at the upper level of the interior, corretti opened up at the same level, triple pilaster clusters on the outside of the drum. (The small flap on Alb. 500 is erroneous in showing an arch or entablature cutting across the high altar space at corretti level.) Bibliography includes Heinrich Thelen, 70 disegni di Francesco Borromini dalle collezioni dell'Albertina di Vienna (Rome, Gabinetto Nazionale delle Stampe, 1958), 17-18, cat. 30-31 and pl. IV; Portoghesi, Borromini (1967/90), fig. L; Kiene, "Palazzo della Sapienza," 260-261, figs. $39-41$. The publication hypothesis and the late date for Alb. 499-500 seem to be gaining consensus: see Connors, "Sebastiano Giannini," 207-208; Kieven, Vom Bernimi bis Piranesi, 67-68, cat. no. 12; and Raspe, Architektursystem, 157, n. 135 , figs. 44-45.

${ }^{41}$ It would be similar to the hexagonal tower which crowns the triangular hunting lodge built by Francesco Contini in Palestrina in honor of the wedding of Prince Maffeo Barberini with a Giustiniani bride. See Sandro Benedetti, "Guarini ed il barocco romano," Guarino Guarini e linternazionalità del Barocco (Turin, 1970), 729 and figs. 20-21; Paolo Portoghesi, Roma barocca (London, 1970), 278, fig. 463; Isa Bella Barsali and Maria Grazia Branchetti, Ville della campagna romana, Lazio 2 (Milan, 1975), 31-33 and 311-13; Francesco Paolo Fiore, "Francesco e Giovanni Battista Contini," Ricerche di Storia dell'Arte 1-2 (1976): 197-210, figs. 6 and 7; M. Fagiolo dell'Arco and S. Carandini, L'effimero barocco, 2 vols. (Rome, 1977-1978), 2: fig. 88; Scott, "S. Ivo," 300, n. 28.

${ }^{42}$ See the discussion of cupolas on Renaissance central buildings in Günter Urban, "Die Kirchenbaukunst des Quattrocento in Rom," Römisches Jahrbuch für Kunstgeschichte 9/10 (1961/62): 203-212. The rule holds true even for the most complex plans in Giovanni Battista Montano, Libro primo: Scielta d. vari tempietti antichi ... (Rome, 1624); idem, Architettura con diversi ornamenti cavati dall'antico, ed. Calisto Ferrante (Rome, 1636); and the three MS volumes of Montano in Sir John Soane's Museum, London: I sette libri della architettura di Giovan Batista Montani Recolte e disigniate dal antiquita di Roma da me con mo(?) mta diligenza non piu viste in luce Curiosi a ognia bel ingenio di tal sienza e virtu). It also holds for buildings like the baths of Viterbo shown by Giuliano da Sangallo (Falb, Il taccuino senese, pl. 8), and for medieval centralized buildings like the Lombard church of S. Sofia in Benevento (Hans Belting, "Studien zum Beneventanischen Hof im 8 . Jahrhundert," Dumbarton Oaks Papers 16 [1962]: 176).

${ }^{43}$ Cesare Ripa, Nova Iconologia (Padua, 1618), cited in Ost, "Universitätskirche," 124-125, figs. 21-22; the ornament was applied under Alexander VII.

${ }^{44}$ G. T. Rivoira, Roman Architecture (Oxford, 1925), 166 ff.; K. LehmannHartleben and J. Lindros, "Il Palazzo degli Orti Sallustiani," Acta Instituti Romani Regni Sueciae 4 (1935) (Opuscula Archaeologica, I), 196-227; G. de Angelis d'Ossat, "La forma e la costruzione delle cupole nell'architettura romana," Atti del III Convegno Nazionale di Storia dell'Architettura (1938) (Rome, 1940), 223-250; Ost, "Universitätskirche," 108, fig. 8; Erik Hansen, La 'Piazza d'Oro' e la sua cupola (Analecta Romana Instituti Danici, 1 Supplementum) (Copenhagen, 1960); Friedrich Rakob, "LITUS BEATAE VENERIS AUREUM. Untersuchungen am 'Venustempel' in Baiae," Mitteilungen des Deutschen Archaeologischen Instituts. Römische Abteilungen 68 (1961): 114-129; William MacDonald, The Architecture of the Roman Empire, I (New Haven and London, 1965), 131; 2 (1986), 220-237; Richard Schofield, "Florentine and Roman Elements in Bramante's Milanese Architecture," in C. H. Smyth and G. C. Garfagnini, eds., Florence and Milan: Comparisons and Relations, 2 vols. (Florence, 1989), 1: 209; Andrea Moneti, “Nuovi sostegni all'ipotesi di una grande sala cupolata alla 'Piazza d'Oro' di Villa Adriana," Analecta Romana Instituti Danici 20 (1992): 67-92; John Pinto and William MacDonald, Hadrian's Villa and Its Legacy (New Haven and London, 1995), 224-228 (my thanks to John Pinto for allowing me to see the relevant chapters prior to publication).

${ }^{45}$ Rudolf Wittkower, Art and Architecture in Italy 1600-1750 (Harmondsworth and Baltimore, 1973), 208.

${ }^{46}$ Sanfelice's first design of 1713 for the church of the Nunziatella at Pizzofalcone in Naples was in the shape of a star, according to Bernardo De Dominici, Vite de' pittori, scultori, ed architetti napoletani (Naples, 1743-1743), 4: 507, quoted in Alastair Ward, The Architecture of Ferdinando Sanfelice (New York and London, 1988), 168-171: "Fece il disegno della chiesa de' Padri Gesuiti sopra Pizzofalcone, che idea più bella non si poteva vedere, avendo fatta la pianta a forma di stella, con gli altari situati in isola in ogni angolo di essa, e li quadri riportati da angeloni di stucco per levare l'acuto dello spicolo, e le finestre, anche a forma di stella, coverta la detta chiesa da una cupola così angolata, che più bella non si poteva desiderare; ma perché quei Reverendi Padri non poterono avere certo sito, che necessitava per detta chiesa, fu necessitato il detto Sanfelice con sommo suo dispiacere di formare il nuovo disegno, col quale presentemente se ne vede fabbricata la chiesa." SantiniAichel's church of St. John Nepomuk in Bestvina (c. 1720) was in the shape of a star, as was the even more complex plan of the church dedicated to the same patron on the Green Mountain near Zd'ár nad Sázavou (1719-1720). See Thomas DaCosta Kaufmann, "Jan Blazej Santini Aichel," Macmillan Encyclopedia of Architects, 3 vols. (New York, 1982), 3: 660-662; and Michael Young, Santimi-Aichel's Design for the Convent of the Cistercian Monastery at Plasy in Western Bohemia (New York, 1994), figs. 151-152 and 161-163.

${ }^{47}$ ASR, Corporazioni religiose femminili, Agostiniane, S. Lucia in Selci, vol. 3704, fasc. 2, illustrated in Portoghesi, Borromini nella cultura europea, fig. 154; Del Piazzo, Ragguagh, 90, no. 128, and pl. XLVIII. The sketch is tiny, done on a sheet folded in half and then again into quarters, each of which measures 13.6 by $10.2 \mathrm{~cm}$.

${ }^{48}$ Hülsen, Il libro di Giuliano da Sangallo, 12, fol. 6; Montano, Scielta, pls. 2 and 65 (where the ruin is restored under the influence of Antonio da Sangallo the Younger's project for S. Giovanni dei Fiorentini). 
${ }^{49}$ Franz Ehrle, S.J., Roma al tempo di Giulio III. La pianta di Roma di Leonardo Bufalini del 1551 (Città del Vaticano, 1911), Foglio T: "Basilica et porticvs Caii et Lvcii Avgvsti nepotvm facta ab eo," an identification that comes from Bartolommeo Marliani, Urbis Romae topographia (Rome, 1544), 82, as Ehrle points out on page 27. Pirro Ligorio (Libro ... delle antichità di Roma, nel quale si tratta de' Circi, Theatri, et Anfitheatri. Con le paradosse del medesimo autore, quai confutano la commune opinione sopra vari luoghi della città di Roma [Venice, 1553], 39v-40r) doubted the identification and thought that the location of the basilica could be proven by inscriptions at the Ionic temple of S. Maria Egiziaca. Fioravante Martinelli, in Roma ricercata (Rome, 4 th ed., 1664), 97-98, made Minerva Medica a building of the Republic: "tempio di Ercole Callaico fatto da Bruto, e detto il Callutio, per corrottione di Callaico." See also Rodolfo Lanciani, Storia degli scavi di Roma, 4 vols. (Rome, 2nd ed., 1990), 3: 170-173; Francis Haskell and Nicholas Penny, Taste and the Antique (New Haven and London, 1981), 269-71; and L. Richardson, Jr., A New Topographical Dictionary of Ancient Rome (Baltimore and London, 1992), 269-270.

${ }^{50}$ See especially $\mathrm{H}$. Winfeld-Hansen, " $L$ 'hexaconque funéraire de l'area sub divo du cimitière de Prétextat à Rome," Acta ad Archaeologiam et Artium Historiam Pertimentia (Istituto di Norvegia in Roma) 4 (1969): 61-93, which contains many of the antiquarian drawings. See Montano, Scielta, pls. 41 and 50; Hülsen, Il Libro di Giuliano da Sangallo, fol. 8, with commentary on p. 15; Ashby, "The Bodleian MS," fol. 91 (pl. x); idem, "Dessins inédits de Carlo Labruzzi," Mélanges d'archéologie et d'histoire 23 (1903): 389; Rivoira, Roman Architecture, 188-190; Hubertus Günther, "Studien zum venezianischen Aufenthalt des Sebastiano Serlio," Münchner Jahrbuch der bildenden Kunst 32 (1981): 69-72; idem, Das Studium der Antiken Architektur in den Zeichnungen der Hochrenaissance (Tübingen, 1988), 146, 366-371, and pls. 88b and 113a. The location, near the intersection of the Via Appia and the Via Appia Pignatelli, is best seen on L. Canina, La prima parte della Via Appia dalla Porta Capena a Boville (Rome, 1853), 2: pl. ix, 2 and 3. This building is not often cited in the context of S. Ivo, but it is at least mentioned by Benevolo, "Il tema geometrico," 3 .

${ }^{51}$ Uffizi $426 \mathrm{Ar}$ and $1651 \mathrm{Ar}$, in Wurm, Baldassarre Peruzzi, figs. 43 and 468.

${ }^{52}$ The Peruzzi plan also makes all six apses equal, but in fact the apse opposite the entrance is larger than the others and slightly horseshoe-shaped.

${ }^{53}$ The drum buttresses of S. Ivo were neither as massively simple as those of the "hexaconque funéraire" nor so fussy and complex as they later became. In the Barberini phase they were about 7 palmi wide, consisting of a pilaster face of 5 palmi and narrow one-palmo membretti on either side. During the Chigi alterations of 1659-1660 another pilaster, 3 palmi wide, was added to the face of each buttress to make a triple pilaster cluster, "per ridurre li ornamenti di detto tamburo in un'ordine reale di architettura composto per ingentilirlo, $\mathrm{e}$ farlo più nobile, che pareva, che restasse troppo sodo rispetto alli doi ordini molto ornati, e suelti del teatro, che li restono sotto" (ASR U 115.403r; cf. Cirielli and Marino, "Il complesso della Sapienza," 44; my thanks to Elisabeth Kieven for pointing out to me the importance of these changes). It should be noted that the "Porta Pia" motifs above the pilaster clusters, added in the Pamphilj phase, were designed to match the robust Barberini buttresses beneath, and are therefore rather simpler than the Chigi triple-cluster buttresses now below them.

${ }^{54}$ Roma ricercata nel suo sito e nella scuola di tutti gli antiquari... (Rome, 1644; 2nd ed., 1650; 3rd illus. ed., 1658); cf. Ludwig Schudt, Le guide di Roma (Vienna and Augsburg, 1930), 251-252.

${ }^{55} \mathrm{I}$ am in full agreement with Steinberg (Borromini's San Carlo, 374-379) and Kieven (Von Bernimi bis Piranesi, 68, n. 2) on this point. A third line of thought, proposed by Kevin Johnson, "In Ivonem Explanationes: The Meaning and Purpose of S. Ivo alla Sapienza," Artibus et Historiae 5 (1982): 100, looks for the source of the plan in the triangular macrocosmic diagrams of Robert Fludd. This too I find unconvincing: Fludd's triangle bears only a generic resemblance to the plan of the church, and Fludd was generally treated with skepticism in the scientific circles around Galileo. The diagram is in Robert Fludd, Utriusque Cosmi ... Historia (Oppenheim, 1617), 1 (De Macrocosmi Historia), trac. 1, bk. 1, 20. See also Thomas Fuller, The Worthies of England (1662) (London, 1811), 60 (Kepler taunted Fludd with the hieroglyphic character of his diagrams); Frances Yates, Theatre of the World (Chicago, 1969), 42-79 (a positive assessment of Fludd's Vitruvianism); Allen Debus, "The Sun in the Universe of Robert Fludd," Le soleil à la Renaissance (Brussels and Paris, 1965), 259-277; idem, Robert Fludd and His Philosophical Key (New York, 1979), 17-19 (on the critiques of Mersenne and Gassendi).

${ }^{56}$ See especially Scott, "S. Ivo," 298-301.
${ }^{57}$ Giannini, Opera, pl. X, "secondo la prima Idea, e Disegno del detto Cavalier Boromino." In his preface Giannini says that Borromini "diede principio alla Chiesa, che nella Pianta forma la figura di un Ape, Arma gentilizia di quel Pontefice." There are two compelling reasons for accepting an early date for the bee plan, apart from the heraldic arguments that John Scott has adduced. First, it still shows the original direct entrances from the side corridors, which were blocked under Alexander VII in 1659-1660. Second, the triangular staircases shown at the top of the plan are the vestige of an early system of vertical circulation (built only on the south side) designed to connect the sacristies flanking the high altar with the hexagonal chambers above them. They are mentioned twice in the misure: "un altro vano per accomodare una scala in testa al portico vecchio in un angolo della sacrestia" (ASR U 115.14r-v); "Sagrestia a mano manca [i.e., epistle side] dell'altar maggiore verso il Sig.r Pallamolla... muro fatto in detto per murare il piano della scaletta a muro pieno, che andava sopra il nicchione della chiesa longo palmi 10 alto palmi 11 regguagliato sopra li scalini, che si sono lasciati per non tagliare, o indebolire la fabrica" (ASR $\mathrm{U} 115.350 \mathrm{r}$ ). In a retreat from the ASR plan, the generating triangle on the bee plan (not drawn but findable on the basis of the pilaster faces) has been reduced so that its points no longer fall in the side corridors. The walls are thus noticeably thicker. The altar chapel has been redesigned without the columnar exedra; its side walls are aligned with a point at the center of the church (near the eye of the bee). The print, in summary, is the only other piece of graphic evidence, aside from the ASR drawing, from the Barberini pontificate. See below on the "star of Solomon" print from the same volume and the reasons for dating it to the eighteenth century.

${ }^{58}$ Fagiolo, "Domus Sapientiae," 152; Scott, "S. Ivo," 298-301. A good example of correspondence, though not exact matching, between vault and pavement patterns is in the Lateran Baptistery, restored by Urban VIII in 1625; see Ann Sutherland Harris, Andrea Sacchi (Oxford, 1977), 84-87, nos. 53-61.

${ }^{59}$ F. Macedo, Archigymnasii Romanae Sapientiae ab Alexandro VII. Pont. Max. perfecti, lustrati, consecrati postridie idus Novembri descriptio (Rome, 1661), 12: "Architectura mirabili, Apis volantis (gentile id fuit symbolum) speciem imitante" (cf. Scott, "S. Ivo," 298, n. 17.) Macedo (1596-1681) did not impress the eighteenth-century biographer of the République des lettres, Jean Pierre Nicéron, who comments on his abundant if shallow disputations and writings, including 150,000 verses, and adds "Tout ce detail aurout pû entrer dans la Charlatanerie des Sçavans de Mencken, s'il l'avoit sçu; \& il y aurout fort bien figuré" (Mémoirs pour servir à l'histoire des hommes illustres dans la République des lettres [Paris, 1729-1745], 31:314).

${ }^{60}$ ASR U 113.399r.

61 " "II]n guisa della venuta dello Spirito Santo che porta la vera Sapienza" (ASR U 115.42v and U 198.52v); cf. Scott, "S. Ivo," 313, n. 126.

${ }^{62}$ However, a notice of 19 May 1729 speaks of Barberini arms on certain unspecified doors: "Dovendo... per la cappella cardinalizia, nella chiesa della Sapienza, non si potè addobbarla perchè la floreria era spogliata, perchè parte venduti gli apparati $\mathrm{e}$ in parte mandati a Benevento. Gli beneventani vendettero anche le bussole delle porte con le armi di Urbano VIII" (E. Scatassa, in Valesio, Rassegna bibliografica 17 (1914): 140).

${ }^{63}$ Paul Fréart de Chantelou, Journal du voyage du Cavalier Bernin en France, ed. L. Lalanne (Paris, 1885); English translation by Margery Corbett, Diary of the Cavaliere Bernini's Visit to France, ed. Anthony Blunt and George Bauer (Princeton, 1985), 34; and Bernini's remarks of 1659/60 (speaking of the colonnade of St. Peter's) on the perfection of the oval form, "che seppe unire con il bello, il proprio, et il necessario. Il bello essendo questa forma circolare più grata all'occhio più perfetta in se stessa" (BAV, Chigi H.II.22, fol. 109v, in Heinrich Brauer and Rudolf Wittkower, Die Zeichnungen des Gianlorenzo Bernini [Berlin, 1931], 70, n. 1).

${ }^{64}$ Martinelli-D'Onofrio, Roma, 216 (see n. 13). The translation is based on fol. $274 \mathrm{v}-275$ of the MS, with the assistance of a transcription of Borromini's marginal note made in 1957 and kindly shown to me by Heinrich Thelen.

${ }^{65}$ See Spada's note to Rasponi of 1656, "Si manda una scrittura del Cavaliere Borromino in risposta à certi miei quesiti, dove al numero 7.o spiega il modo, che si propose nell'edificio di questo Tempio [S. Giovanni in Laterano]; poi che si come la melodia delle voci nasce da numeri, così la bellezza delle fabriche, professa nascere parimente da numeri, e che tutte le parti habbino una tale proportione, che un'apertura di compasso, senza mai muoverlo, le misuri tutti" (Klaus Güthlein, "Quellen aus dem Familienarchiv Spada zum römischen Barock [II]," Römisches Jahrtuch für Kunstgeschichte 19 [1981]: 210). While it is of 
course true that the hexagon and circle in S. Ivo could be constructed with a single opening of the compass, this does not hold for the arcs swung from the angles of the triangle.

${ }^{66}$ Contract dated 19.III.1661, final misura 19.IV.1662; see Del Piazzo, Ragguagli, 235-236.

${ }^{67}$ Among the supporters of this hypothesis are Benevolo, "Il tema geometrico," 1; Ost, “Universitätskirche,” 109; Fagiolo, “Domus Sapientiae," 151; Fagiolo, "La Sapienza di Borromini," 350; Du Prey, "Solomonic Symbolism," (1986), 59, fig. 2; Blunt, Borromini, 114-15, fig. 83. Steinberg (Borromini's San Carlo, 378, n. 41) does not accept the star hypothesis but gives a good account of those who do.

${ }^{68}$ On Juvarra's plan of S. Ivo of 1704-1716 in Vincennes, see Andrea Barghini, Juvarra a Roma. Disegni dall'atelier di Carlo Fontana (Turin, 1994), fol. 59r (I was able to examine a copy of this booklet thanks to the kindness of Sarah McPhee). On three plans of 1721-1722 by Schlaun, Westfalisches Amt für Denkmalpflege in Münster, see Theodor Rensing, Johann Conrad Schlaun. Leben und Werk des westfälischen Barockbaumeisters (n.p., n.d.), 11; Franz Graf Wolff Metternich, "Römisches bei Kirchenentwürfen des westfälischen Architekten Johann Conrad Schlaun," Scritti di storia dell'arte in onore di Mario Salmi (Rome, 1963), 3: 239-261; Kiene, "Palazzo della Sapienza," 254, n. 163. A. E. Brinckmann, Die Baukunst des 17. und 18. Jahrhunderts in den romanischen Ländern (Berlin, 1919), 342 (cf. Steinberg, Borromini's San Carlo, 378) says that the Schlaun plans were drawn with two intersecting triangles, a mistaken observation that reflects Brinckmann's own belief about the origin of the plan: "Hier durchdringen sich zwei gleichseitige Dreiecke, so dass ein regelmässiger Sechseckstern entsteht." However, his concluding words are quite accurate: "sechs Kreise auf Spitzen und Seitemitten eines Dreiecks."

${ }^{69}$ Giannini, Opera, 1720, double-page print following $\mathrm{pl}$. XLV but unnumbered, often reproduced, e.g. by Eberhard Hempel, Francesco Borromini (Vienna, 1924), 115, fig. 34; Ost, "Universitätskirche," 101, fig. 1; and Du Prey, "Solomonic Symbolism" (1986), 61, fig. 4.

${ }^{70}$ Not even the opening of the high altar, contrary to what Benevolo maintains in "Il tema geometrico," 5-6.

${ }^{71}$ ASR U 79.23r.

${ }^{72}$ Laurie Nussdorfer, Civic Politics in the Rome of Urban VIII (Princeton, 1992), 205-227.

${ }^{73}$ ASR U 198.87 ff.; Del Piazzo, Raggruagli, 233.

${ }^{74}$ Joseph Connors, "Borromini, Hagia Sophia and S. Vitale," forthcoming in Architectural Studies in Memory of Richard Krautheimer (Mainz, 1996). My thanks to Silvia Foschi for showing me the relevant chapter of her tesi di laurea, "Le fortune critiche della chiesa di S. Vitale in Ravenna," Facoltà di Storia dell'Architettura dell'Università di Venezia, 1992, in which possible influences of early Christian architecture on S. Ivo are discussed.

${ }^{75}$ On Hadrian's villa plans, see the remark of Virgilio Spada of 7.X.1656, defending departures from the right angle in Borromini's Lateran: "si può vedere ne i disegni della Villa Adriana in mano dell'Eminentissimo Barberino, dove si vedono non meno di una dozzena di Tempietti, tutti di linee curve" in Klaus Güthlein, "Quellen aus dem Familienarchiv Spada zum römischen Barock [II]," Römisches Jahrbuch für Kunstgeschichte 19 (1981): 209.

${ }^{76}$ One of the S. Vitale drawings is the plan on Alb. 1433, inscribed "A[v]uto del P[ad]r[e] Castello di S.to Paolo / disse ess[e]re edificata in Ravena / delli esarchi di giustiniano Imperatore / a similitudine di S.ta Sofia in Costantinopoli." The drawing, but not padre Castelli, is mentioned by Portoghesi, Borromini, 17, and Raspe, Architektursystem, 136, n. 38.

${ }^{77}$ D. Mariani Armellini, Bibliotheca Benedictino-Casinensis sive Scriptorum Casinensis Congregationis alias S. Justinae Patavinae (Assisi, 1731), prima pars, 92-97; Antonio Favaro, Intorno ad un discorso sopra la calamita del P. D. Benedetto Castelli (Rome, 1884); idem, Amici e corrispondenti di Galileo Galileo. XXI. Benedetto Castelli (Venice, 1908), reprint, ed. P. Galluzzi (Florence, 1983); Giulio Pittarelli, "Notizie storiche sull'insegnamento della matematica nell'università di Roma," Roma 6 (1928): 529-536; 7 (1929): 17-28 and 61-76; G. L. Masetti Zannini, La vita di Benedetto Castelli (Brescia, 1961); Stillman Drake, "Benedetto Castelli," Dictionary of Scientific Biography (New York, 1971), 3: 115-117; A. De Ferrari, "Benedetto Castelli," Dizionario Biografico degli Italiani (Rome, 1978), 21: $686-690$. That Borromini's padre Castelli was the famous scientist can be shown by process of elimination. The matriculation lists for Benedictines at S. Paolo (which I was able to glimpse fleetingly in the archives of the basilica thanks to the archivist Don Stefano, and which are published in Matricula Monachorum
Congregationis Casinensis Ordinis S. Benedicti, I (1409-1699) [Cesena, 1983], 164-166) show that no other Castelli joined the order in Rome in the seventeenth century. These lists do not mention Benedetto either, but that can be explained by the fact that he joined the order in Brescia. His presence in the community in Rome is proved by the many letters he wrote from his rooms at the Benedictine house at S. Callisto in Trastevere, where the monks of S. Paolo fuori le mura habitually lived because of malaria in the area around the basilica. Heinrich Thelen has also identified Castelli as the scientist; my thanks to him for a lively discussion of the topic

${ }^{78}$ Benedetto Castelli, Trattato delle selciate delle strade antiche, Biblioteca Apostolica Vaticana, MS Barb. Lat. 6461, ca. 104-105, ed. Antonio Favaro, in Amici e corrispondenti di Galileo (1908), 103-105 (or 1983, 843-845); Johannes Kepler, Strenna, Seu de Nive Sexangula, trans. C. Hardie as The Six-Cornered Snowflake, with essays by B. J. Mason and L. L. Whyte (Oxford, 1966).

${ }^{79}$ Benedetto Castelli, Delle misure dell'acque correnti, bound with Demostrazioni geometriche della misura dell'acque correnti (Rome, 1628).

${ }^{80}$ Antonio Favaro, Le opere di Galileo Galilei. Edizione Nazionale (Florence, 1890-1909), 13: 358 on Castelli's appointment to the Sapienza.

${ }^{81}$ Favaro, Opere di Galileo, 14: 296, "... fui pregato da una mano di gentilhuomini di garbo e litterati di spiegarli i principii della geometria, come feci con mia particolare consolazione, perchè m'incontrai in ingegni non dozzinali, $\mathrm{ma}$ in particolare in quattro di quelli buoni, con i quali spesso si fece honoratissima ricordanza del gran merito di V.S.: e mi creda che sono restati stupefatti, e tanto più quanto che prima erano aversissimi al nome di lei et alle cose sue, delle quali o non sapevano niente affatto, o le havevano apprese storpiate bene; ma hora sono acconci in altro modo, $\mathrm{e}$ intendo che studiano alla gagliarda."

${ }^{82}$ On Berti see Joseph Connors, "Virtuoso Architecture in Cassiano's Rome," Cassiano Dal Pozzo's Paper Museum (London, 1992), 2: 27-28 (Quaderni Puteani, 3).

${ }^{83}$ For Borromini and the geometry of the medieval Lombard mason, see Rudolf Wittkower, Gothic vs. Classic: Architectural Projects in Seventeenth-Century Italy (New York, 1974), 90, and S. Kappner, "Francesco Borrominis Ausbildungsjahre an der Mailänder Dombauhütte 1608-1619," Arte Lombarda 108/109 (1994.1-2): 17-18.

${ }^{84}$ Martinelli-D'Onofrio, Roma, 216-217: "E sebene non mancavano al Papa soggetti habili ad ogni impresa reale, nondimeno l'angustia del sito poteva distoglier molti da quella per l'obbligo di obedire al convesso e tondo del teatro, et all'accantonati fianchi con il retto verso la strada, che riquadrandosi il tutto non era per larghezza maggiore di palmi ... e per longhezza di palmi. ... Si che fu scelto il Cav. Borromino, al quale per la vivezza dell'ingegno, per la prattica delle regole Vitruviane, e per l'assuefattione ad imitare l'opere de migliori professori d'architettura antichi Greci e Romani, non dava travaglio il miscuglio de' cantoni, e delle linee dritte e torte, ne la mancanza di lume vivo, conoscendo, che il trofeo del valore dell'architetto nasceva dalle difficoltà, dalle quali veniva travagliato, et essercitato l'ingegno."

${ }^{85}$ John Beldon Scott, "Patronage and the Visual Encomium during the Pontificate of Urban VIII: The Ideal Palazzo Barberini in a Dedicatory Print," Memoirs of the American Academy in Rome (1995): 193-228, especially p. 206, n. 79. Busini himself had departed Rome by 1634.

${ }^{86}$ Blunt, Borromini, 47.

\section{Illustration Credits}

Figure 1. Anderson

Figure 2. De Rossi, Insignium Romae Templorum Prospectus, 1684 (author)

Figure 3. Krönig, Sizilien, pl. 15

Figure 4. Courtauld Institute of Art

Figure 5.ASR, Università 198 (author)

Figure 6. ASR, Università 198 (ASR)

Figures. 7, 8. Modena, Biblioteca Estense

Figures. 9, 10, 11. Adrienne Atwell

Figures. 12, 17, 18. Florence, Uffizi

Figure 13. Rome, Biblioteca Apostolica Vaticana

Figure 14. Vienna, Albertina

Figure 15. ASR, Fondo Agostiniane S. Lucia in Selci (author)

Figure 16. Bufalini, Rome map of 1551, from Ehrle, Roma al tempo di Giulio III (Rome, 1911)

Figures 19, 20.S. Giannini, Opera, vol. I (Rome, 1720) (author) 